\title{
Analysis of a large spatiotemporal groundwater quality dataset, Ontario 2010-2017: Informing human health risk assessment and testing guidance for private drinking water wells
}

\author{
Tessa Latchmore \\ Queen's University - Kingston, Ontario \\ Paul Hynds \\ Technological University Dublin, Paul.Hynds@tudublin.ie \\ R. Stephen Brown \\ Queen's University - Kingston, Ontario
}

See next page for additional authors

Follow this and additional works at: https://arrow.tudublin.ie/ehsiart

Part of the Environmental Sciences Commons

\section{Recommended Citation \\ Tessa Latchmore, Paul Hynds, R. Stephen Brown, Corinne Schuster-Wallace, Sarah Dickson-Anderson, Kevin McDermott, Anna Majury, Analysis of a large spatiotemporal groundwater quality dataset, Ontario 2010-2017: Informing human health risk assessment and testing guidance for private drinking water wells, Science of The Total Environment, Volume 738, 2020, 140382, ISSN 0048-9697, DOI: 10.1016/ j.scitotenv.2020.140382.}

This Article is brought to you for free and open access by the ESHI Publications at ARROW@TU Dublin. It has been accepted for inclusion in Articles by an authorized administrator of ARROW@TU Dublin. For more information, please contact arrow.admin@tudublin.ie, aisling.coyne@tudublin.ie,gerard.connolly@tudublin.ie. Funder: Canadian Foundation for Infectious Diseases (CFID)

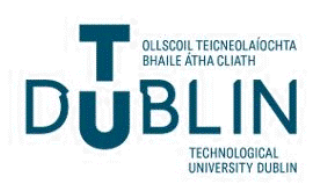




\section{Authors}

Tessa Latchmore, Paul Hynds, R. Stephen Brown, Corinne Schuster-Wallace, Sarah Dickson-Anderson, Kevin McDermott, and Anna Majury 


\title{
Analysis of a large spatiotemporal groundwater quality dataset, Ontario 2010-2017: Informing human health risk assessment and testing guidance for private drinking water wells
}

\author{
Tessa Latchmore ${ }^{\mathrm{a}}$, Paul Hynds ${ }^{\mathrm{b}}$, R. Stephen Brown ${ }^{\mathrm{a}}$, Corinne Schuster-Wallace ${ }^{\mathrm{c}}$, Sarah Dickson-Anderson ${ }^{\mathrm{d}}$, \\ Kevin McDermott ${ }^{\mathrm{e}}$, Anna Majury ${ }^{\mathrm{a}, \mathrm{e}, *}$ \\ a School of Environmental Studies, Queen's University, Kingston, Ontario, Canada \\ b Technological University Dublin, Dublin, Ireland \\ c University of Saskatchewan, Saskatoon, Saskatchewan, Canada \\ ${ }^{\mathrm{d}}$ McMaster University, Hamilton, Ontario, Canada \\ e Public Health Ontario, Kingston, Ontario, Canada
}

\section{H I G H L I G H T S}

- Provincial E. coli sampling data from 239,244 unique wells $(702,861$ samples) analyzed.

- Repeat sampling effects assessed using probabilistic power curves.

- Consolidated aquifers exhibit significantly higher detection rates than unconsolidated $(\mathrm{p}=0.0191)$.

- Geographically- and temporally specific testing guidelines justified across large regions.

- Health risk assessments should consider delineations based on local contamination drivers.

\section{A R T I C L E I N F O}

\section{Article history:}

Received 1 April 2020

Received in revised form 1 June 2020

Accepted 18 June 2020

Available online 20 June 2020

Editor: José Virgílio Cruz

\section{Keywords:}

Private water wells

Groundwater

Detection rates

Risk assessments

Repeat sampling

Testing guidelines
G R A P H I C A L A B S T R A C T

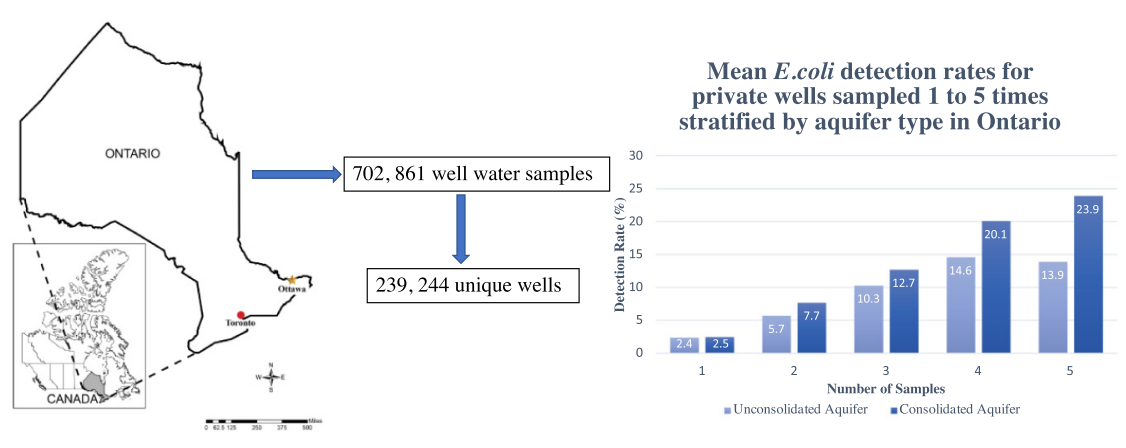

\begin{abstract}
A B S T R A C T
Approximately 1.5 million individuals in Ontario are supplied by private water wells (private groundwater supplies). Unlike municipal supplies, private well water quality remains unregulated, with owners responsible for testing, treating, and maintaining their own water supplies. The primary goal of this study was to assess the effect of repeat sampling of private well water in Ontario and investigate the efficacy of geographically- and/or temporally specific testing recommendations and health risk assessments. The current study combines the Well Water Information System Dataset and the Well Water Testing Dataset from 2010 to 2017, inclusive. These two large existing province-wide datasets collated over an eight-year period were merged using an integrated spatial fuzzy logic and (next)- nearest neighbour approach. Provincial sampling data from 239,244 wells (702,861 samples) were analyzed for Escherichia coli to study the relationship between sampling frequency and Escherichia coli detection. Dataset variables were delineated based on hydrogeological setting (e.g. aquifer type, overburden depth, well depth, bedrock type) and seasonality to provide an in-depth understanding of Escherichia coli detection in private well water. Findings reveal differences between detection rates in consolidated and unconsolidated aquifers $(p=0.0191)$, and across seasons $(p<0.0001)$. The variability associated with Escherichia coli detection rates was explored by estimating sentinel sampling rates for private wells sampled three times, twelve times and twenty-four times per year. As sample size increases on an annual basis, so too does detection rate, highlighting the need to address current testing frequency guidelines. Future health risk assessments for private
\end{abstract}

\footnotetext{
* Corresponding author at: School of Environmental Studies, Queen's University, Kingston, Ontario, Canada.

E-mail address: anna.majury@oahpp.ca (A. Majury).
} 
well water should consider the impact of spatial and temporal factors on the susceptibility of this drinking water source, leading to an increasingly accurate depiction of private well water contamination and the estimated effects on human health.

(c) 2020 Elsevier B.V. All rights reserved.

\section{Introduction}

It is estimated that private groundwater sources (private water wells serving a single household) supply drinking water to 4.1 million Canadians, with Ontario comprising the largest groundwater reliant population, equating to approximately 1.5 million individuals (Statistics Canada, 2016). Unlike water supplies provided and managed through publicly managed systems, private well water quality in Ontario is unregulated, with well owners responsible for testing, treating and maintaining their own drinking water sources (Ministry of the Environment, Conservation and Parks, 2014). Bacteriological testing is available through provincial laboratories in Ontario free of charge, yet testing rates are low relative to the number of wells in the province. For example, during the 12-month period January to December 2015, just 24\% of households using a private water supply had their water tested at least once (Statistics Canada, 2016). Similarly, Maier et al. (2014) studied bacteriological sampling of private well water in southeastern Ontario and reported that between $10.7 \%$ and $12.8 \%$ of wells were tested "somewhat routinely" (3 times per year) during any one study year, while just $0.3 \%$ were tested as per the historic provincial guideline ( 3 times per year) year on year between 2008 and 2012.

Recommendations for private well water testing vary significantly across Canada. For example, five provinces (Nova Scotia, Quebec, New Brunswick, Alberta and British Columbia) recommend testing twice a year (Ministère du Développement durable, de l'Environnement, de la Faune et des Parcs Québec, 2002; British Columbia Ministry of Health Services, 2012; Government of New Brunswick, 2013; Nova Scotia Environment, 2013; Government of Alberta, 2020), with a further three provinces (Saskatchewan, Manitoba and Prince Edward Island) recommending at least one test per year (Government of Saskatchewan, 2012; Government of Manitoba, 2013; Prince Edward Island Department of Environment, Labour and Justice, 2013). Newfoundland and Labrador recommend three times per year, while Public Health Ontario does not currently specify an empiric recommendation (Conservation Corps Newfoundland and Labrador, 2013; Public Health Ontario, 2018). At the federal level, the guideline is to test at a minimum two times per year. Federal recommendations also highlight the need to test at high risk times, such as after heavy rainfall or dry periods, spring and fall, or after a long period of non-use (Health Canada, 2020). These inconsistencies highlight the ambiguity associated with quantifying the presence, frequency, and duration of microbial contamination of private drinking water. Similarly, the microbial quality of drinking water is dependent on a multitude of factors including weather (heavy rainfall, snowmelt), hydrogeological setting (e.g. groundwater vulnerability, recharge rate, preferential flow paths), land use (e.g., proximity of pathogen sources), improper disposal and land application of manure, production and treatment of waste water, septic systems, inadequate attention to well location and/or design, and poor standards of well maintenance and treatment (Charrois, 2010; Di Pelino et al., 2019). However, most testing recommendations do not account for the sitespecific or temporal factors that influence private well susceptibility to microbial contamination, instead relying on more generalized recommendations.

Groundwater and surface water are frequently contaminated by environmental sources of Escherichia coli (E. coli), a globally recognized indicator of fecal contamination employed for routine testing and monitoring (WHO, 2017). E. coli is commensal to the gastrointestinal tract of animals and thus present in feces. Accordingly, detection of E. coli in water suggests recent fecal ingress and the potential presence of enteric pathogens that can cause waterborne gastrointestinal infection (Conway and Cohen, 2015). Murphy et al. (2016) have recently estimated the burden of acute gastrointestinal illness (AGI) attributable to private wells and small water systems in Canada via quantitative microbial risk assessment (QMRA). They estimated that approximately 80,000 (95\% CI 38,466-128,109) cases of AGI likely result from consumption of contaminated groundwater from private wells, compared to 13,000 cases for small groundwater systems and 12,000 cases from small surface water systems. However, quantifying the relationship between private well water quality and adverse health effects is complicated by geographical diversity, significant under-reporting and the lack of private well water surveillance (Richardson et al., 2009; Pons et al., 2015).

Previous studies have assessed the frequency with which indicator bacteria (e.g. E. coli, fecal coliforms, total coliforms) were detected in sampled groundwater wells (Francy et al., 2000; Richardson et al., 2009; Atherholt et al., 2015). Documented detection rates exhibit significant variation, due to fluctuations of indicator bacteria in groundwater associated with season, agricultural cycles, wastewater production/release, and hydrological setting, among others (Atherholt et al., 2015; Atherholt et al., 2017). Further, while the presence (and concentration) of $E$. coli in water supplies at any time indicates some level of contamination susceptibility, the absence of indicators only demonstrates an absence in the sample taken, and not necessarily a resolute absence from the water supply over time (i.e. lack of susceptibility), unless corrective action is taken (Smith et al., 2006; Hynds et al., 2014a). Thus, elucidating the variability of fecal indicator bacteria (FIB) and their presence in groundwater is required to develop regionally- or site-specific sampling recommendations and health risk assessments for private well water users and public health professionals.

The current study sought to assess the effects of repeat sampling on detection rates in private well water in Ontario and investigate whether spatially- and/or temporally- specific testing recommendations are required across spatially extensive regions. Specifically, the aims were to: 1) determine significant differences, if any, between E. coli detection rates and hydrogeological setting (aquifer consolidation, subsoil depth, well depth and bedrock geology); 2) examine the seasonal patterns of E. coli detection rates from private well water across Ontario; and, 3) estimate the number of well water samples required to accurately reflect private well water contamination in Ontario. Study findings will support policy makers in developing recommendations and inform development of tailored risk assessments (e.g. QMRA), thereby enabling evidence-based recommendations for well owners regarding appropriate maintenance and testing practises that are increasingly evidencebased or regionally specific.

\section{Methods}

\subsection{Study area}

Ontario is the second largest province in Canada, covering more than 1 million square kilometres with an estimated population of 14 million people (Statistics Canada, 2016), 10\% of whom reside in rural and/or remote areas (Rural Ontario Institute, 2017). Nearly all of those individuals residing in rural and/or remote areas rely on private water wells as their primary source of drinking water (Charrois, 2010). Accordingly, private well water provides a drinking water supply to $11 \%$ of the Ontario population, or approximately 1.5 million individuals (Statistics Canada, 2016). Based on the current Well Water Information System 
(WWIS), there are approximately 500,000 private water wells in use in the province (MECP, 2019). However, this may be an underestimate as not all wells are documented.

The majority of Ontario (60\%) is underlain by Precambrian bedrock, known as the Canadian Shield (Fig. 1), which is comprised of crystalline igneous, sedimentary and metamorphic rocks (Baldwin et al., 2011). The northernmost parts of the Canadian Shield are dominated by igneous bedrocks, with the central region characterized by sedimentary rocks (Kettles, 1992; Baldwin et al., 2011). Bedrock outcrops are common across the Canadian Shield as a result of scour during periods of glaciation (Levison and Novakowski, 2012; Card and Poulsen, 2013). Sandy to silty tills cover the southern part of the Canadian Shield and southern Ontario, in contrast to the silty and clay tills dominating the northern half of the province (Card and Poulsen, 2013). Fractures represent the predominant groundwater transport mechanism within consolidated aquifers (southeastern Ontario), which consist primarily of sedimentary bedrocks (e.g. limestone, shale, and sandstone). Unconsolidated aquifers throughout the province occur within sand and/or

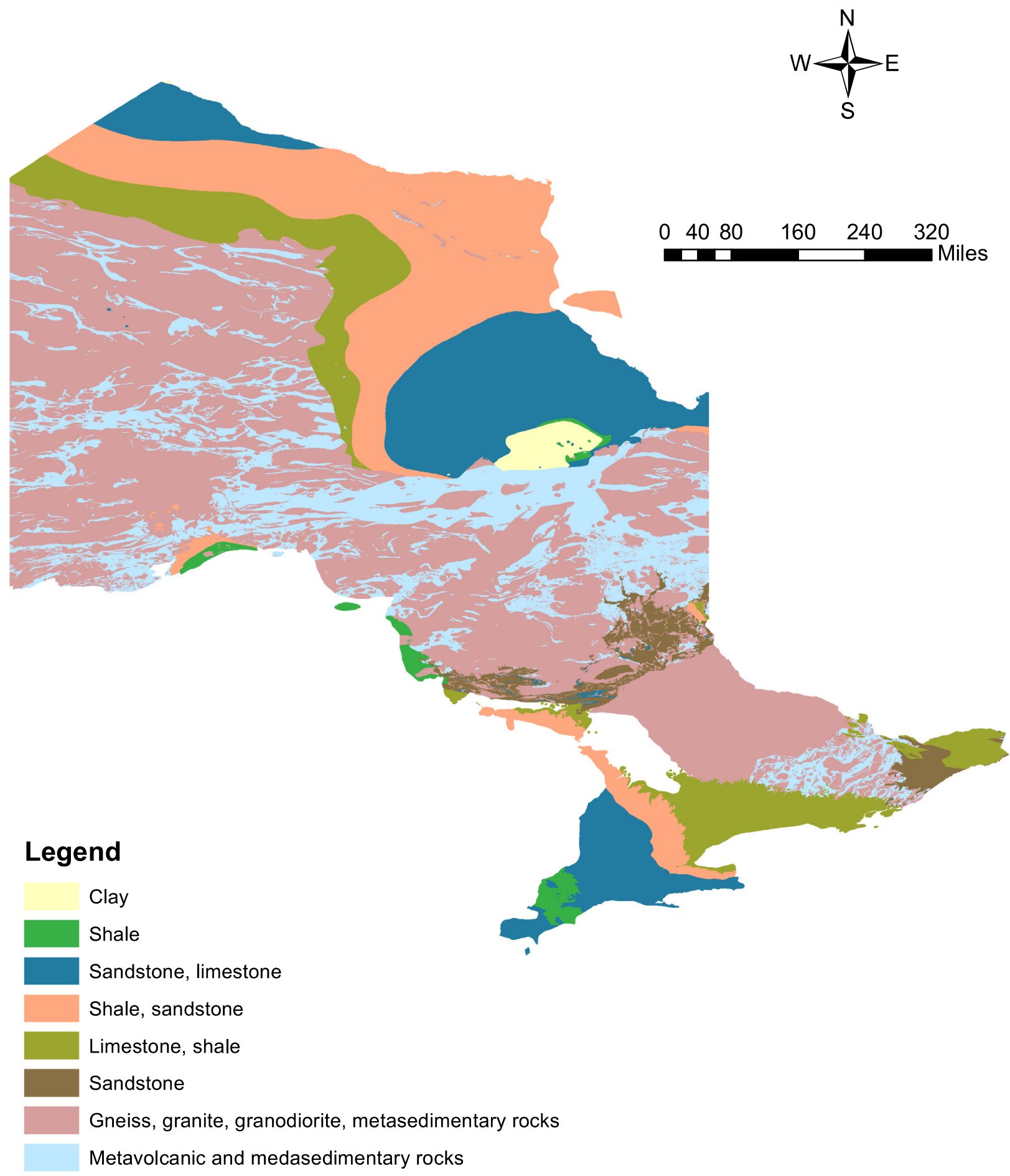

Fig. 1. Bedrock geology of Ontario.

Adapted from: The Ministry of Energy, Northern Development and Mines (2019). 
gravel deposits of glacio-fluvial, glacio-lacustrine, and marine origins with overburden deposits primarily comprising clays, silts and tills (Gao, 2011). Areas of thick (up to $200 \mathrm{~m}$ ) overburden and subsurface glacio-fluvial deposits are not uncommon across areas of southwestern Ontario, whereas thin ( $0-2 \mathrm{~m})$ overburden is pronounced throughout southeastern Ontario (Gao, 2011).

Ontario's climate is classified as humid continental due to the provinces diverse landscape and spatial extent. Northern Ontario is characterized by long, severely cold winters and short, cool to warm summers with the northernmost regions experiencing a subarctic climate (Baldwin et al., 2011). Southwestern Ontario has a moderate humid continental climate with warm to hot and humid summers and cold winters, heavily influenced by The Great Lakes, while central and eastern Ontario experience warm summers with colder, longer winters and significant snowfall. Precipitation trends in the province increases from northwest to southeast which is altered significantly by strong lake and physical effects in the southern and central regions of the province (Baldwin et al., 2011).

\subsection{Data sources}

The current study combined the Well Water Information System (WWIS) dataset and the Well Water Testing Dataset (WWTD) from 2010 to 2017, inclusive. A full description of all data fields used for analyses is presented in Table 1. The WWIS is the authoritative well record data set maintained by the Ontario Ministry of the Environment, Conservation and Parks (MECP). Accordingly, when a well [defined as "any engineered hole made in the ground to locate or to obtain groundwater or to test or to obtain information in respect of groundwater or an aquifer" (MECP, 2019)] is constructed, amended or decommissioned, the individual or company performing the labour (e.g. licensed well contractor) is obligated to report all works to the MECP in compliance with the Wells Regulation (O. Reg. 903) under the Ontario Water Resource Act 1990. This is done by completing a well record form which includes details pertaining to well construction, location, pump test results, geological formation in which the well is situated and general information regarding water quality. The data set contains well records received from 1940 to present day, with approximately 15,000 to 20,000 new well records appended per year (MECP, 2019).

The WWTD contains all results of bacteriological testing performed at the Ontario provincial laboratory. The database is maintained by the province and contains records relating to all private wells tested at its laboratory. Private well owners submit well water for free bacteriological testing to one of the eleven provincial laboratory locations in Ontario using a government issued sample bottle and accompanying requisition. Information documented on the requisition includes well location; i.e., the domestic address of the household served by the sampled supply. All water testing requisitions require the domestic address of the household served by the sampled supply. The domestic address is provided by the well owner and accepted as accurate by the laboratory. The domestic addresses provided by the well owners were cleaned into formatted addresses for autonomous geocoding with the Google Maps Application Programming Interface (API). Google Maps API returned a JavaScript Object Notation formatted address with geocodes (i.e. exact latitude and longitude coordinates given in degrees). All submitted samples are processed and analyzed for Total Coliforms (TC) and E. coli via direct membrane filtration and culture, in compliance with ISO/IEC Standard 170255:2017. The number of $E$. coli and TC colony forming units (CFU) is counted, up to a maximum of $80 \mathrm{CFU} / 100 \mathrm{~mL}$ unless there is crowding and/or confluent and/or non-identifiable microbial growth on the membrane filter with evidence of TC and/or E. coli present. A test with this outcome is reported as "No Data: Overgrown with Target (NDOGT)". Given there is no count (CFU/mL) associated with NDOGT, samples with this reporting outcome were excluded from the study. Only E. coli results (excluding TC results) have been included in the current study as it represents a specific indicator of recent fecal ingress and, if present, suggests a potential threat to public health. The recommended acceptable limit of $E$. coli is 'none' detectable in a $100 \mathrm{~mL}$ sample (Health Canada, 2020).

The WWTD-WWIS dataset was created by merging the WWTD with the WWIS. These two datasets rely on different geo-spatial coordinate systems. Geospatial joining of the WWTD and WWIS was therefore accomplished via an iterative, nearest neighbour, fuzzy logic (exact string matching) custom algorithm. This task was executed on a High-Performance Computer Cluster (HPC) using the haversine distance calculated between geo-coordinates of the WWTD source address and the WWIS well records. Samples were specifically matched to sources using minimum haversine distance; i.e., averaging was not used, and thus the merged dataset was smaller than the initial dataset as sources not appropriately matched were removed from the dataset. The matching efficiency of the join was determined by examining the ratio of the well and distance groupings. A ratio of one well to one distance ensured that the join was $100 \%$ efficient.

Table 1

Description of variables used in detection rate analysis.

\begin{tabular}{|c|c|c|c|}
\hline Variable & Measurement & Source and description & \\
\hline Escherichia coli & $\mathrm{CFU} / 100 \mathrm{~mL}$ & WWTD & $0 \mathrm{CFU} / 100 \mathrm{~mL}-81 \mathrm{CFU} / 100 \mathrm{~mL}$ \\
\hline Detection rate & $\begin{array}{l}\text { Proportion of } E \text {. coli positive wells: } \\
\frac{\text { number of wells in which E.coli bacteria were detected }}{\text { number of wells in that sample cohort }}{ }^{1}\end{array}$ & Current study & \\
\hline Aquifer type & $\begin{array}{l}\text { Consolidated } \\
\text { Unconsolidated }\end{array}$ & WWIS & Derived based on geological formation data \\
\hline Well depth & $\begin{array}{l}\text { Shallow } \\
\text { Moderate } \\
\text { Moderate/deep } \\
\text { Deep }\end{array}$ & WWIS & $\begin{array}{l}\text { Derived based on geological formation data } \\
\text { (Interquartile ranges) }\end{array}$ \\
\hline Overburden depth & $\begin{array}{l}\text { Shallow } \\
\text { Moderate } \\
\text { Moderate/deep } \\
\text { Deep }\end{array}$ & WWIS & $\begin{array}{l}\text { Derived based on geological formation data } \\
\text { (Interquartile ranges) }\end{array}$ \\
\hline Season & $\begin{array}{l}\text { Summer (June-August) } \\
\text { Fall (September-November) } \\
\text { Winter (December-February) } \\
\text { Spring (March-May) }\end{array}$ & WWTD & $\begin{array}{l}\text { Derived based on date of water sample collection } \\
(\mathrm{dd} / \mathrm{mm} / \mathrm{yy})\end{array}$ \\
\hline Bedrock type & $\begin{array}{l}\text { Limestone } \\
\text { Shale } \\
\text { Sandstone } \\
\text { Granite }\end{array}$ & WWIS & Derived based on geological formation data \\
\hline
\end{tabular}

\footnotetext{
${ }^{1}$ E.g. one-sample cohort, two-sample cohort, three-sample cohort, four-sample cohort, five-sample cohort.
} 


\subsection{Variable delineation}

Select variables from both the WWIS and the WWTD were chosen for analysis of $E$. coli detection rates in private well water in Ontario (Table 1). Detection rate was defined as the proportion of $E$. coli positive wells (i.e., the number of wells in which $E$. coli bacteria are detected relative to the number of wells in a sampled population; from Atherholt et al., 2015). Detection rates were analyzed relative to aquifer type (consolidated and unconsolidated) to determine if $E$. coli detection varied by hydrogeological setting (i.e., transport pathway). It is the responsibility of the individual or company constructing the well to report the geological formation in which the well is constructed in the well record. Geological formation data is inputted to the WWIS by the well contractor, but is not obligatory and thus may be missing from some records. Further, the mechanisms for submitting this data to the WWIS have evolved over time as the process evolved from manual to digital, enabling more robust data to be captured currently versus historically.

Geological setting was further delineated into four categories (i.e., depth delineations; Table 2) based on the interquartile range of available well data, as follows: 1 ) depth to bedrock (within consolidated aquifers), or 2) well depth (within unconsolidated aquifers). Depth to bedrock was considered appropriate for analyses of consolidated aquifers as overburden [defined as all top- and subsoils overlying the parent material, i.e., aquifer] acts as the primary protective layer for mitigating contamination via natural attenuation (e.g. filtration, microbial predation) (Hynds et al., 2014a). Well depth was used as it has been shown to represent a risk factor for bacterial contamination in private wells (Allevi et al., 2013). Private wells located in consolidated aquifers were further delineated based on bedrock types (Table 1). Lastly, samples were stratified by the provincial seasonality of Ontario to elucidate temporal E. coli detection patterns. Each well was grouped based on the number of times it was tested on an annual basis (one to five samples/ annum) with each well thus assigned an individual detection rate. Information regarding reasons for sample submission, irrespective of submitted sample number (i.e. wells re-tested to confirm effectiveness of treatment or maintenance following contamination event) is not recorded and thus, it was not possible to explore the timing of repeated sampling. Wells sampled on $\geq 6$ occasions were excluded from analysis. While high sample numbers are useful, they are not representative of testing frequency across the province and may introduce bias due to

Table 2

Depth delineations for hydrogeological setting based on IQR of well data.

\begin{tabular}{lllll}
\hline Aquifer type & $\begin{array}{l}\text { Q1: } \\
\text { Shallow }\end{array}$ & $\begin{array}{l}\text { Q2: } \\
\text { Moderate }\end{array}$ & $\begin{array}{l}\text { Q3: } \\
\text { Moderate/deep }\end{array}$ & $\begin{array}{l}\text { Q4: } \\
\text { Deep }\end{array}$ \\
\hline Overburden & $0-6 \mathrm{ft}$ & $7-20 \mathrm{ft}$ & $21-50 \mathrm{ft}$ & $>50 \mathrm{ft}$ \\
$\quad$ (consolidated) & $0-2 \mathrm{~m}$ & $2-6 \mathrm{~m}$ & $6.4-15 \mathrm{~m}$ & $>15 \mathrm{~m}$ \\
Consolidated (well & $0-60 \mathrm{ft}$ & $60-100 \mathrm{ft}$ & $100-160 \mathrm{ft}$ & $>160 \mathrm{ft}$ \\
depth) & $0-18 \mathrm{~m}$ & $19-30 \mathrm{~m}$ & $30-49 \mathrm{~m}$ & $>49 \mathrm{~m}$ \\
Unconsolidated & $0-43 \mathrm{ft}$ & $44-75 \mathrm{ft}$ & $76-125 \mathrm{ft}$ & $>125 \mathrm{ft}$ \\
& $0-13 \mathrm{~m}$ & $13.5-22.5 \mathrm{~m}$ & $23-38 \mathrm{~m}$ & $>38 \mathrm{~m}$ \\
\hline
\end{tabular}

excessively high or low detection rates depending on sampling motivation. Finally, well water samples are submitted voluntarily, not only in Ontario but also across Canada, and therefore well water data collected is from self-selected individuals choosing to assess the quality of their private drinking water supply. As such, it is important to acknowledge that there may be some voluntary bias in the sampling data, as it is based on a strategic, randomized sampling protocol but entirely at the discretion of the well owner or user.

\subsection{Statistical analyses}

All statistical analyses and graphical visualizations were performed using R (version 3.2.1) and RStudio@ (version 1.1.447) with the addon packages ggplot2 (version 3.2.1) and tidyr (version 1.0.0), with significance determined based upon a $p$-value $<0.05$ by convention (Agresti and Tarantola, 2018). Variables were tested for linearity using quantile-quantile (Q-Q) plots. Kruskal-Wallis tests were performed to explore associations between non-parametric categorical variables (i.e. consolidated and unconsolidated, depth category, bedrock type and seasons). Post-hoc multiple pairwise-comparison tests (between groups) were performed if the Kruskal-Wallis test yielded a significant result, to quantify between group associations (Bonferroni correction).

Observed detection rates from sampled wells were used to estimate a detection probability for any given number of samples by using a probability estimation equation (Eq. (1)):

$p(x)=1-(1-p)^{x}$

where $p(x)$ is the detection probability for $x$ number of samples and $p$ is the $E$. coli detection for a single sample. Power curves were then applied to spatial (location and depth) and temporal (season) E. coli detection rates to assess repeat sampling effects and to estimate the number of samples required to achieve "sentinel" detection rates (e.g. sampling three times per year). Previous work by Atherholt et al. (2015) examined the influence of repeat sampling on indicator bacteria detection rates in groundwater using similar probability estimates.

\section{Results}

The original dataset contained 795,023 samples from 253,136 unique wells. Samples with missing or incomplete data related to E. coli count or geological formation were excluded (92,162 samples; 13,893 wells) as the information could not be used to delineate variables and/or calculate corresponding detection rates (Table S1). The final dataset contained 702,861 samples from 239,244 wells submitted to the provincial laboratory for E. coli analysis from January 1st, 2010 through December 31st, 2017. The largest proportion of samples were submitted during summer ( $34.3 \% ; n=241,367)$, followed by spring (26.3\%; $n=185,318)$, fall $(25.1 \% ; n=176,166)$ and winter $(14.2 \%$; $n=100,010)$. Overall, $50.1 \%$ of wells $(119,819)$ were sampled once, with the remaining 119,425 sampled more than once. Annual E. coli detection rates increased in concurrence with increasing sample number

Table 3

Annual E. coli (EC+) detection rates (DR) delineated by sample number ( $N=1$ to 5 ) tested by the Ontario provincial laboratory from 2010 to 2017.

\begin{tabular}{|c|c|c|c|c|c|c|c|c|c|c|c|c|c|c|c|}
\hline \multirow[t]{2}{*}{ Year } & \multicolumn{3}{|c|}{ Wells sampled once } & \multicolumn{3}{|c|}{ Wells sampled twice } & \multicolumn{3}{|c|}{ Wells sampled three times } & \multicolumn{3}{|c|}{ Wells samples four times } & \multicolumn{3}{|c|}{ Wells sampled five times } \\
\hline & $\mathrm{N}$ & $E C+$ & $\mathrm{DR}(\%)$ & $\mathrm{N}$ & $E C+$ & DR $(\%)$ & $\mathrm{N}$ & $E C+$ & DR (\%) & $\mathrm{N}$ & $E C+$ & DR (\%) & $\mathrm{N}$ & $E C+$ & $\mathrm{DR}(\%)$ \\
\hline 2010 & 32,028 & 789 & 2.5 & 9718 & 676 & 7 & 4317 & 513 & 11.9 & 2007 & 363 & 18 & 968 & 151 & 23.2 \\
\hline 2011 & 31,187 & 788 & 2.5 & 9520 & 711 & 7.5 & 4210 & 466 & 11.1 & 1979 & 312 & 15.8 & 1029 & 227 & 22.1 \\
\hline 2012 & 32,257 & 596 & 1.8 & 9520 & 558 & 5.9 & 4095 & 371 & 9.1 & 1798 & 222 & 12.3 & 923 & 154 & 16.7 \\
\hline 2013 & 29,209 & 760 & 2.6 & 9036 & 753 & 8.3 & 3917 & 462 & 11.8 & 1858 & 302 & 16.3 & 997 & 201 & 20.2 \\
\hline 2014 & 28,278 & 614 & 2.2 & 8877 & 664 & 7.5 & 3760 & 395 & 10.5 & 1736 & 276 & 15.9 & 961 & 183 & 19 \\
\hline 2015 & 29,060 & 572 & 1.9 & 8624 & 519 & 6 & 3520 & 363 & 10.3 & 1605 & 237 & 14.8 & 834 & 166 & 19.9 \\
\hline 2016 & 32,206 & 437 & 1.4 & 9145 & 409 & 4.5 & 3168 & 223 & 7 & 1430 & 143 & 10 & 712 & 91 & 13.1 \\
\hline 2017 & 32,456 & 467 & 1.4 & 8566 & 480 & 5.6 & 3042 & 309 & 10.2 & 1366 & 162 & 11.9 & 759 & 147 & 19.4 \\
\hline
\end{tabular}

Bold numbers represent the detection rates. 


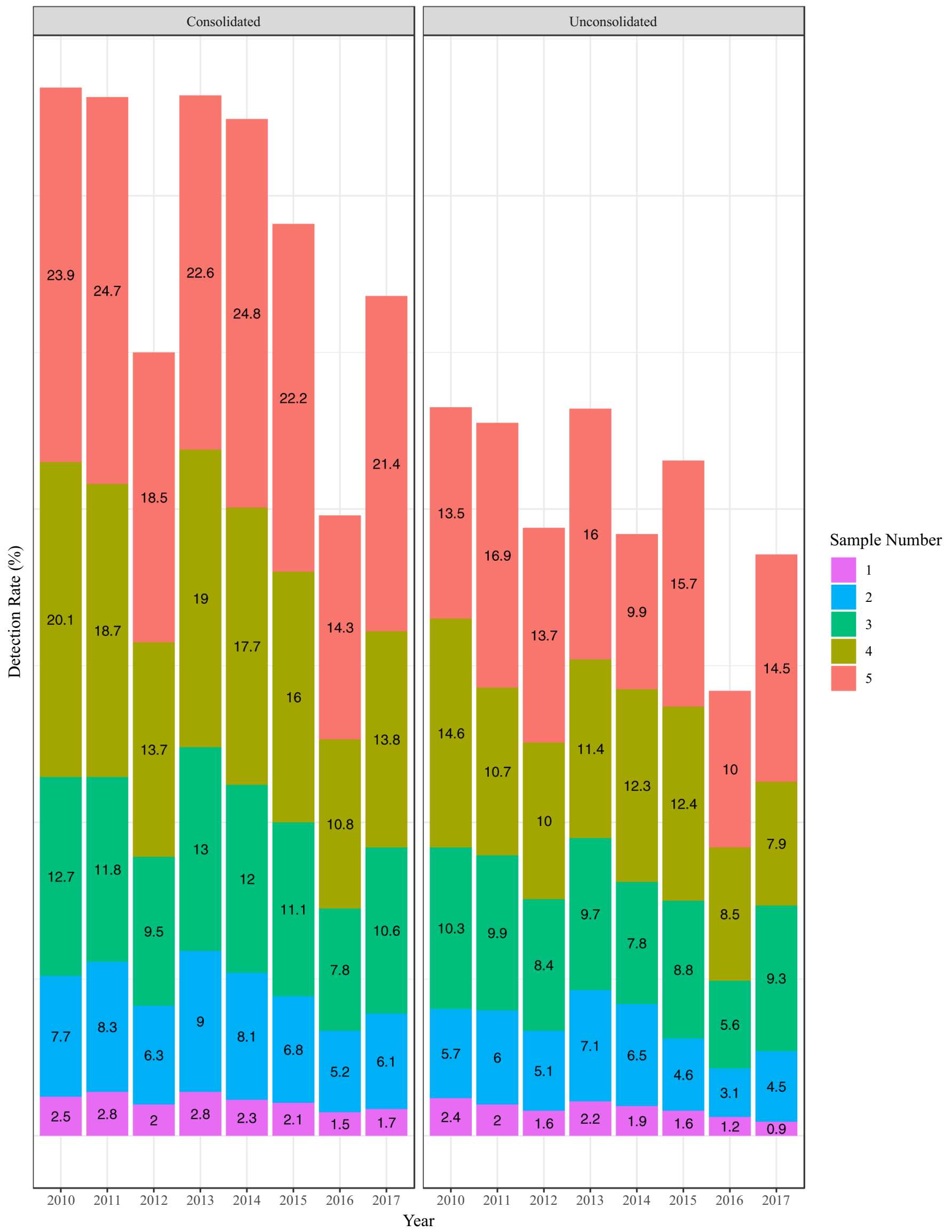

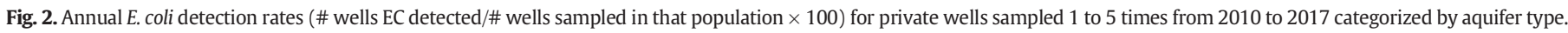



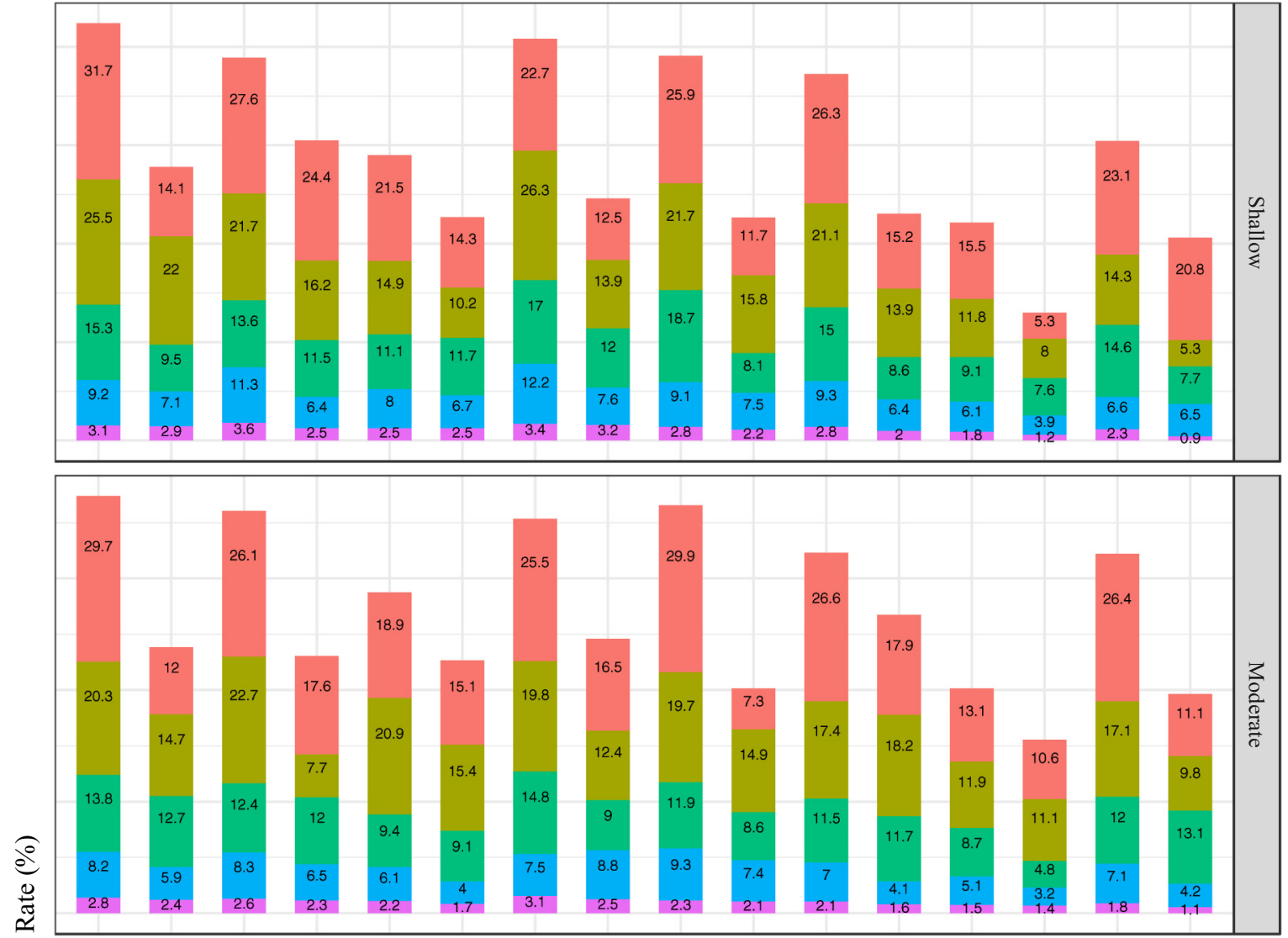

Sample Number

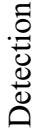
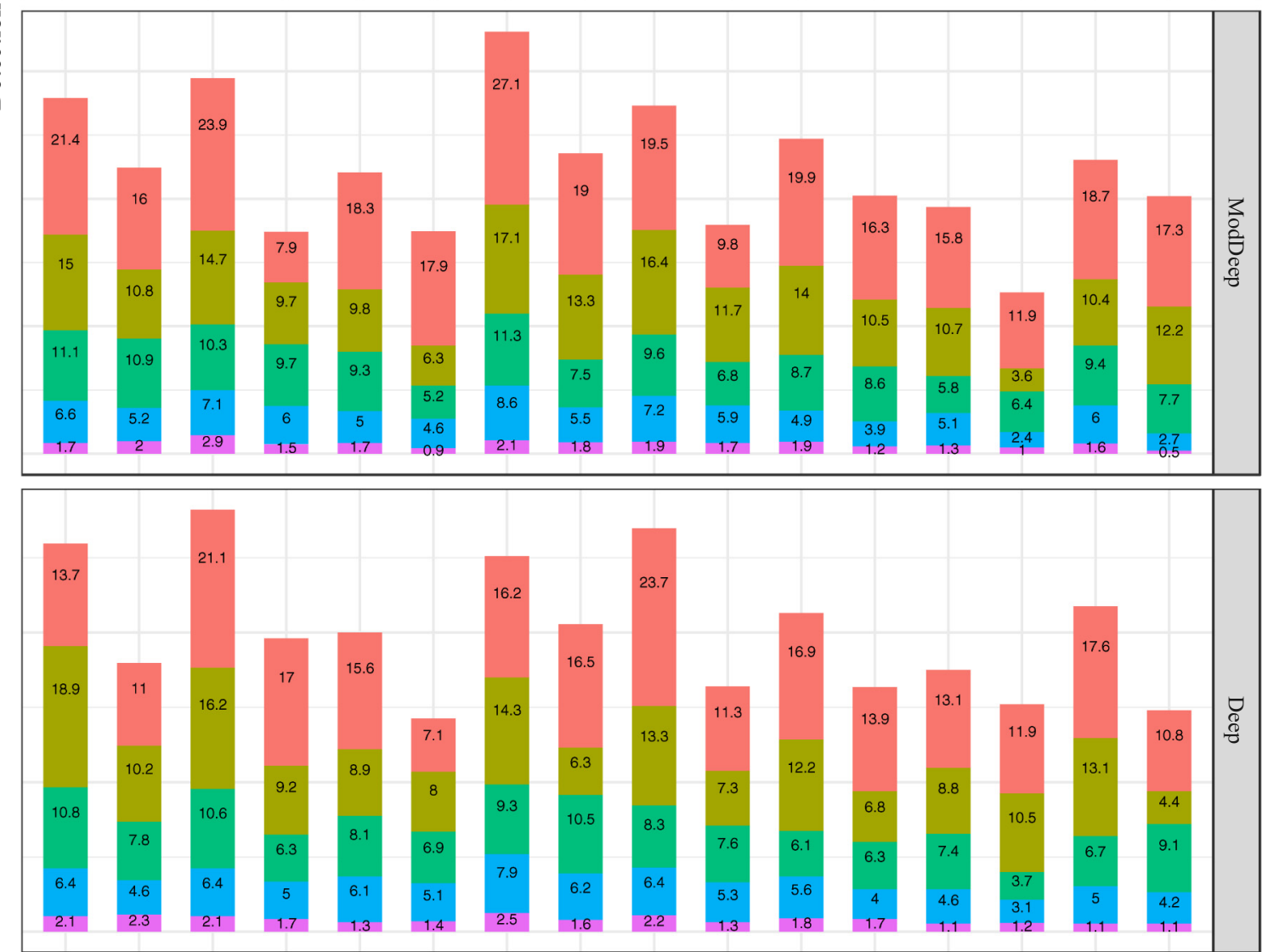

2010C 2010U 2011C 2011U 2012C 2012U 2013C 2013U 2014C 2014U 2015C 2015U 2016C 2016U 2017C 2017U Year $(\mathrm{C}=$ Consolidated Aquifer, $\mathrm{U}=$ Unconsolidated Aquifer $)$

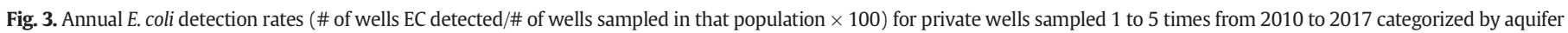
type and well depth. 
across the eight-year period (Table 3), ranging from 1.4\% (2016, 2017) to $2.6 \%$ (2013) for wells sampled once per year. Annual detection rates were markedly lower in 2016 across all sampling frequencies (1-5 samples) compared to the other study years. For example, mean $E$. coli detection rates for wells sampled five times from 2010 to 2013 were $23.2 \%, 22.1 \%, 16.7 \%$ and $20.2 \%$, respectively; however, the same sampling frequency in 2016 returned a mean detection rate of $13.1 \%$.

\subsection{Hydrogeological setting}

A total of 156,033 wells (458,910 samples) were geographically associated with consolidated aquifers and 83,211 wells (243,951 samples) associated with unconsolidated aquifers. As shown (Fig. 2), annual E. coli detection rates based on one-off sampling ranged from $1.5 \%$ (2016) to $2.8 \%$ (2013) in consolidated aquifers and $0.9 \%$ (2017) to $2.4 \%$ (2010) in unconsolidated aquifers. Where two or more submissions were made, E. coli detection rates ranged from $5.2 \%(N=2$; $2016)$ to $24.7 \%(N=5 ; 2011)$ in consolidated aquifers and from $3.1 \%$ $(\mathrm{N}=2 ; 2016)$ to $16.9 \%(\mathrm{~N}=5 ; 2011)$ in unconsolidated aquifers. Statistical analyses (Table 6 ) indicate that annual mean E. coli detection rates within consolidated aquifers were significantly higher than unconsolidated aquifers, irrespective of well/subsoil depth and sampling season $(p=0.0191)$.

Annual $E$. coli detection rates delineated by well depth classification and aquifer type are presented in Fig. 3. As shown (Table 4), for wells located in consolidated aquifers, shallow (0-6 ft) and moderate (7-20 ft) overlying sub-soils depths were associated with significantly higher detection rates than wells with deep $(>50 \mathrm{ft})$ overlying subsoils $(p<0.0001)$. Similarly, annual mean E. coli detection rates associated with categorically shallow wells ranged from 2.0\% (2015) for a single sample to $31.7 \%$ (2010) for five samples, with shallow wells within unconsolidated aquifers exhibiting an annual mean detection rate of $1.8 \%$ (2017) and 24.4\% (2011) for one and five samples, respectively (Fig. 3). Similar trends were noted within all other depth delineations, as private wells located in consolidated aquifers exhibited consistently higher detection rates compared to unconsolidated aquifers over the eight-year study period.

Within consolidated aquifers, $56.7 \%(88,497)$ of wells were geographically associated with limestones, $28.3 \%(44,226)$ granites, $6.8 \%$ $(10,632)$ sandstones, and $6.6 \%(10,294)$ shales. Additional geological formations were present in the dataset but were excluded due to small sample sizes. Annual E. coli detection rates were highest for wells located in limestones, followed by shales, granites and sandstones (Fig. 4). Statistical analyses indicate a significant mean detection rate difference between the four bedrock types $(p<0.0001)$; wells associated with sandstone bedrocks had significantly lower detection rates than wells associated with limestones, granites and shales (Table 5). Bedrock specific detection rates were highest during 2013, ranging from $1.5 \%$ to $20.6 \%$ in sandstones for wells sampled 1 to 5 times; in limestones, the same sampling frequencies during 2013 resulted in detection rates of $3 \%$ to $24.1 \%$. Detection rates in 2013 in shales were

\section{Table 4}

Results of post-hoc multiple pairwise comparison (Bonferroni correction) of private well water E. coli detection rates across Ontario, 2010-2017 stratified by overburden depth and well depth.

\begin{tabular}{lcccc}
\hline Variable & $\begin{array}{l}\text { Overburden } \\
\text { depth }\end{array}$ & $\begin{array}{l}\text { Well depth } \\
\text { (unconsolidated) }\end{array}$ & & $\begin{array}{l}\text { Well depth } \\
\text { (consolidated) }\end{array}$ \\
\cline { 2 - 2 } & $\mathrm{p}$ & $\mathrm{p}$ & $\mathrm{p}$ & 0.4493 \\
\hline Shallow $=$ moderate & 0.4482 & & 0.0089 & $<0.0001$ \\
Shallow $>$ moderate/deep & $<0.0001$ & & $<0.0001$ & $<0.0001$ \\
Shallow $>$ deep & $<0.0001$ & & $<0.0001$ & $<0.0001$ \\
Moderate $>$ moderate/deep & $<0.0001$ & & $<0.0001$ & $<0.0001$ \\
Moderate $>$ deep & $<0.0001$ & $<0.0001$ & 0.0477 \\
Moderate/deep $>$ deep & 0.0472 & 0.0557 & \\
\hline
\end{tabular}

slightly higher than in limestones, at $3.8 \%$ to $29.4 \%$ for 1 to 5 samples, respectively (Fig. 4).

\subsection{Temporal patterns}

E. coli detection rates differed significantly with respect to sampling season (Table 6 ); rates were markedly higher during summer and fall months compared to spring $(p=0.0016)$ and winter $(p=0.0001)$, irrespective of geological setting (Table 7 ). More specifically, private wells sampled once and five times during summer months exhibited mean E. coli detection rates of 3.2\% and 36\%, respectively (Fig. 5). Mean detection rates were lowest during winter months ranging from $2.2 \%$ for a single submission to $15.3 \%$ for five samples. Mirroring the annual trend across the entire province, $E$. coli detection rates were markedly lower during 2016 across all seasons compared to other years.

Detection rates varied significantly between aquifer type (consolidated/unconsolidated) and sampling season; rates calculated for both aquifer types were significantly higher during summer and fall months compared to winter and spring among all wells ( $p<0.0001$ ) (Table 7). More specifically, annual $E$. coli detection rates for wells sampled during summer months based on five total samples ranged from 25.7\% (2011) in unconsolidated aquifers to $36 \%$ (2010) in consolidated aquifers (Fig. 5). During winter months, this rate decreased to 3.8\% (2016) within consolidated aquifers and 5\% (2015) within unconsolidated aquifers.

\subsection{E. coli detection rates: repeat sampling}

Detection rates increased in concurrence with increasing sample number among all respective delineations. Calculated power curves (via detection probability estimation) were analyzed for accuracy by comparing the power curve predictions with actual detection rates associated with wells sampled one to three times per year for Ontario and aquifer type. Probability estimations using power analyses were applied to spatial (Fig. 7a to d) and temporal (Fig. 7e) E. coli detection rates to assess repeat sampling effects. A summary of estimates within the respective delineations is presented in Fig. 6 for wells sampled three (previous Ontario guideline), twelve (monthly) and twenty-four times (fortnightly) per year. Within consolidated aquifers, probability estimation indicates that an annual $E$. coli detection rate of $8.5 \%$ would occur if each well within the sample population was sampled three times per year, compared with a detection rate of $6.5 \%$ for three samples per year within unconsolidated aquifers.

Calculated detection rates varied considerably based on subsoil/well depth delineations, with probability estimation applied to assess the effect of overburden and well depth on repeat sampling effects (Fig. 7a to c). For example, using Fig. 6, sampling during fall and summer months, in shallow and moderate depth wells, probability estimates indicate an E. coli detection rate of $10 \%$ if all wells were sampled three times per year increasing to $50 \%$ if all wells were sampled 24 times per year. However, if sampling occurred during spring and winter months, E. coli would be detected in $7 \%$ ( 3 samples) and $38 \%$ of wells ( 24 samples). For shallow and moderate depth wells $(<75 \mathrm{ft}$ ) located in unconsolidated aquifers, $E$. coli would be detected in $12 \%$ of wells if each well was sampled three times per year, and $56 \%$ of all wells if each well was sampled 24 times per year. During the winter months, the same sampling regimen would detect E. coli in $4 \%$ and $22 \%$ of wells, respectively.

\section{Discussion}

Understanding E. coli detection in private well water, and the effects of sample frequency, timing and hydrogeological setting can assist with development of evidence-based sampling strategies, health risk assessments, and interventions to ensure adequate human health protection from waterborne pathogens. Human health risk assessments (e.g. 

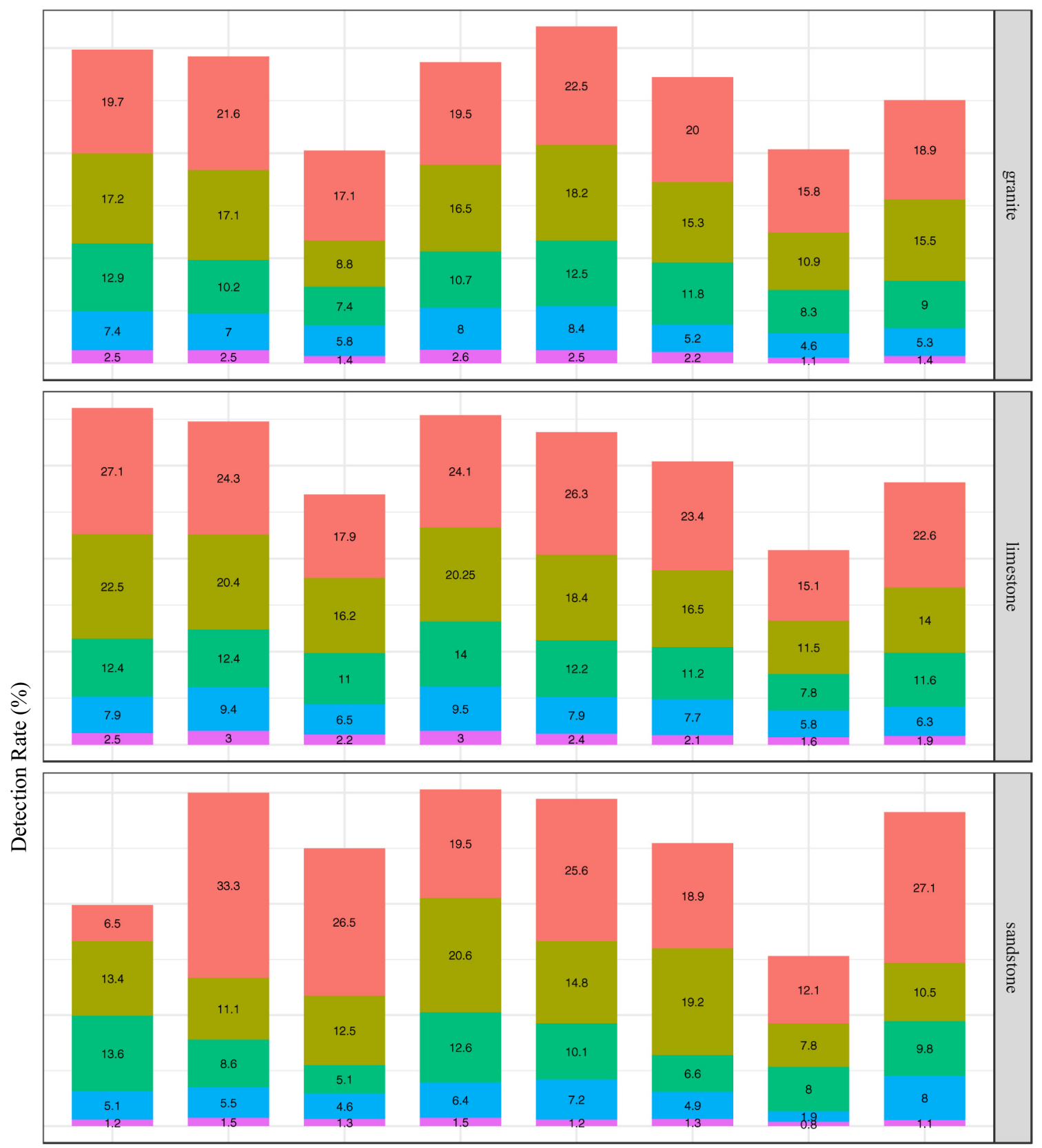

Sample Number

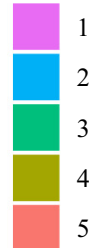

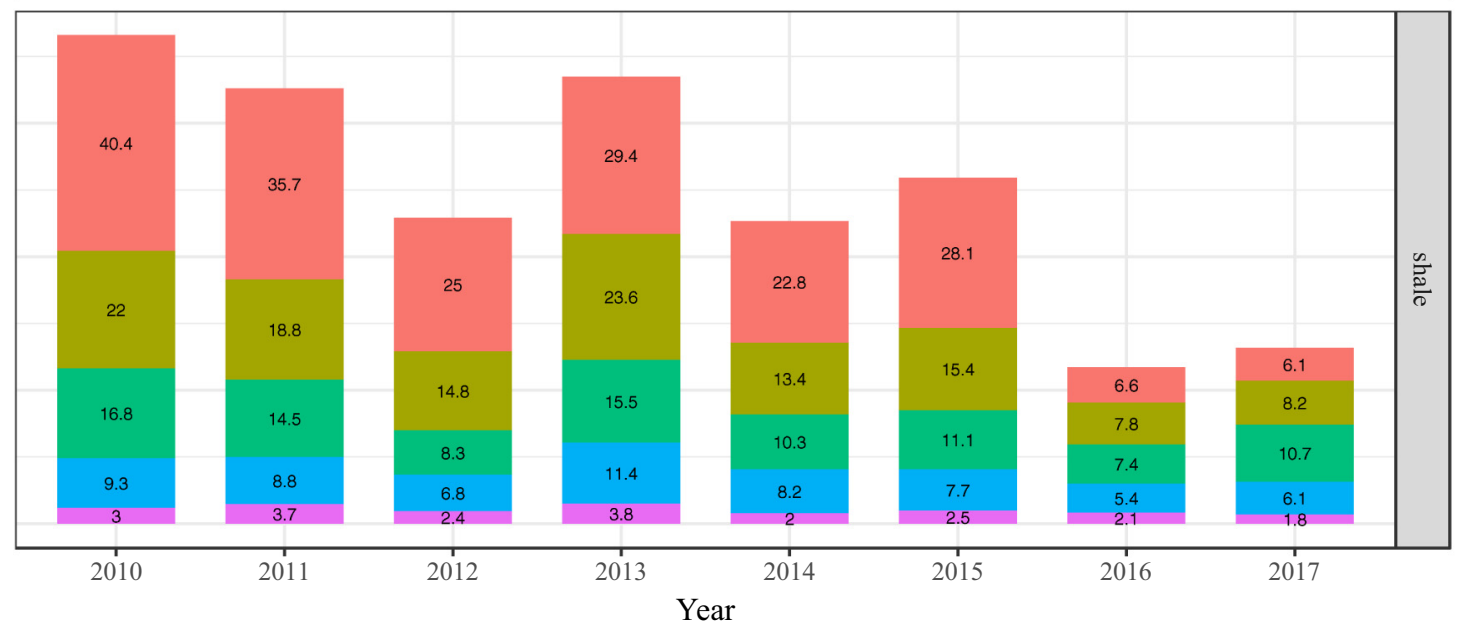

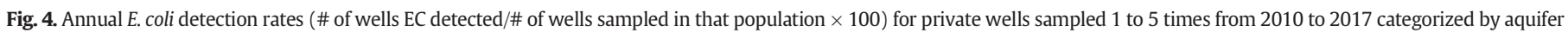
type and well depth. 
Table 5

Results of post-hoc multiple pairwise comparison (Bonferroni correction) testing of private groundwater $E$. coli detection rates across Ontario, 2010-2017 stratified by (categorical) bedrock type in consolidated aquifers.

\begin{tabular}{lcll}
\hline & Granite & Limestone & Sandstone \\
\hline Limestone & 0.0063 & - & - \\
Sandstone & $<0.0001$ & $<0.0001$ & - \\
Shale & 0.00013 & 0.1803 & $<0.0001$ \\
\hline
\end{tabular}

Table 6

Results of Kruskal-Wallis test for significance between Ontario private well water E. coli detection rates among dataset variables ${ }^{\mathrm{a}}, 2010-2017(p<0.05)$.

\begin{tabular}{lcr}
\hline Variable & Test-statistic & \multicolumn{1}{c}{$\mathrm{p}$} \\
\hline Aquifer type & 21.17 & 0.0191 \\
Seasons (all) & 28.89 & $<0.0001$ \\
Seasons (consolidated aquifer) & 30.73 & $<0.0001$ \\
Seasons (unconsolidated aquifer) & 25.05 & $<0.0001$ \\
Consolidated (overburden depth) & 5.31 & $<0.0001$ \\
Unconsolidated (well depth) & 4.33 & $<0.0001$ \\
Bedrock type & 117.45 & $<0.0001$ \\
\hline
\end{tabular}

a See Table 1 for group delineations.

Table 7

Results of post-hoc multiple pairwise comparison (Bonferroni correction) of private well water E. coli detection rates across all samples, 2010-2017 stratified by season.

\begin{tabular}{lccccc}
\hline Variable & All samples & & Consolidated aquifer & & Unconsolidated aquifer \\
\cline { 2 - 2 } & $\mathrm{p}$ & & $\mathrm{p}$ & $\mathrm{p}$ \\
\hline Spring < Summer & 0.0016 & & 0.0018 & 0.0003 \\
Spring < Fall & 0.0177 & & 0.0075 & 0.0231 \\
Spring = Winter & 0.1254 & & 0.0864 & 0.6233 \\
Summer = Fall & 0.1488 & & 0.4682 & 0.4694 \\
Summer > Winter & $<0.0001$ & $<0.0001$ & $<0.0001$ \\
\hline
\end{tabular}

QMRA) frequently rely on overly generalized (meta)data from the scientific literature, census data or national/provincial monitoring programmes (e.g. Hynds et al., 2014b; Murphy et al., 2016), and thus are not regionally-specific nor do they appropriately address the influence of seasonality or local hydrogeology. Additionally, testing frequency recommendations for private well water in Ontario, and the rest of Canada, are not currently evidence-based and have not been tested with respect to sample location, timing (i.e. seasonality) or periodicity (Maier et al., 2014). Study findings may be employed by multiple stakeholders including policymakers, health practitioners, and the general public to guide (top down) and undertake (bottom up) increasingly focused assessments of drinking water quality and, consequently, enhance human health risk assessment of contaminated private groundwater supplies. Moreover, due to the spatial extent of the study area, diverse climatic and geological regions, and the 8-year study period, findings may be readily transferable to other regions, countries and/or continents.

\subsection{Spatiotemporal variability of E. coli detection}

Analysis of E. coli detection rates from 239,244 Ontario private wells (702,861 samples) identified significant differences across respective delineations, thereby highlighting the spatiotemporal variability of groundwater quality. Previous studies have noted that well owners frequently consider that if, when tested, there is no evidence of bacterial contamination (i.e. negative index sample), it is unnecessary to submit another sample (Jones et al., 2006; Kreutzwiser et al., 2010; Roche et al., 2013; Ugas et al., 2019). The proportion of wells tested once over the eight-year study period ( $n=119,819 ; 49.8 \%$ ) would seem to strongly support this finding, highlighting a significant gap with regard to well owners' knowledge of bacterial contamination of private well water and consequently the capacity to appropriately perceive risk.

Detection rates for wells sampled one to five times in 2013 were notably higher than those calculated for other study years, while 2016 detection rates were significantly lower. In 2013, torrential rains caused major flooding which affected many rural areas in the province, while significant droughts characterized much of 2016 (Canadian Meteorological and Oceanographic Society, 2018). Flooding events have been shown to negatively impact groundwater quality by mobilizing pathogens in sediments and the surrounding environment (Levy et al., 2016). A recent scoping review examining the relationship between surface water flooding, groundwater contamination and human health outcomes found that among studies comparing pre- and postflooding water quality via FIB, higher FIB concentrations were consistently found post-flooding (Andrade et al., 2018). High intensity and/ or duration precipitation also increases transport of FIB to groundwater from surface and subsurface sources (Hynds et al., 2014a; Atherholt et al., 2017) while lower concentrations of FIB have been found during drought periods (Mosley, 2015). This likely explains the higher detection rates in 2013 across all delineations and the lower detection rates in 2016.

Seasonally, summer and fall had significantly higher detection rates compared to winter and spring. Both summer (June to August) and fall (September to November) months in Ontario experience higher monthly rainfall as well as higher single day rainfall events compared to winter and spring months (Government of Canada, 2019). Mean annual precipitation ranges from 800 to $1100 \mathrm{~mm}$ in Southern Ontario and 500 to $700 \mathrm{~mm}$ in Northern Ontario (MECP, 2019). Additionally, agricultural practises (i.e. grazing, spreading) across Ontario traditionally commence in the late spring or early summer. Precipitation, warmer weather, and agricultural practises have all been shown to negatively impact groundwater quality and influence $E$. coli detection (Richardson et al., 2009; Hynds et al., 2012; Atherholt et al., 2017). Private well owners may be faced with an increased risk of well water contamination during warmer months, which may potentially result in an increased risk of waterborne infection. To date, few health risk assessments of private well water have sought to include temporal water quality variability and thus may not reflect the true burden of illness associated with private well water. Rates of AGI have been shown to exhibit distinct seasonal patterns with peaks in the summer months among those who rely on private groundwater sources (Schuster et al., 2005; Galway et al., 2014; Wallender et al., 2014). The elevated risk of contamination and consequent infection is not captured by currently available risk assessments and therefore the human health burden may not be appropriately quantified or interpreted. Further, well water sampling recommendations and guidance rarely account for the seasonal differences in detection rates and instead provide an annual recommendation without addressing the inherent variability of well water contamination. Accordingly, sampling during high-risk periods (i.e. summer months, heavy rainfall events) may prove to be more effective when assessing the quality of private well water (Health Canada, 2020).

Wells located in consolidated aquifers exhibited significantly higher detection rates than those located in unconsolidated aquifers. Bedrocks are typically characterized by primary porosity and fracture interconnectivity (secondary porosity), with many bedrock aquifers in Ontario having thin overburden available to provide natural attenuation from contaminant infiltration and/or recharge (Gao et al., 2006). Wells with shallow and moderate depths of overlying subsoil also exhibited significantly higher detection rates than wells with moderate/deep and deep depths. Previous studies have found that wells associated with thinner overlying subsoil are typically more susceptible to contamination due to decreased contaminant attenuation (Gonzales, 2008; Allevi et al., 2013; Hynds et al., 2014a). Similarly, bedrock geology has previously been identified as a risk factor for contamination, with previous studies reporting higher levels of source susceptibility when associated with 

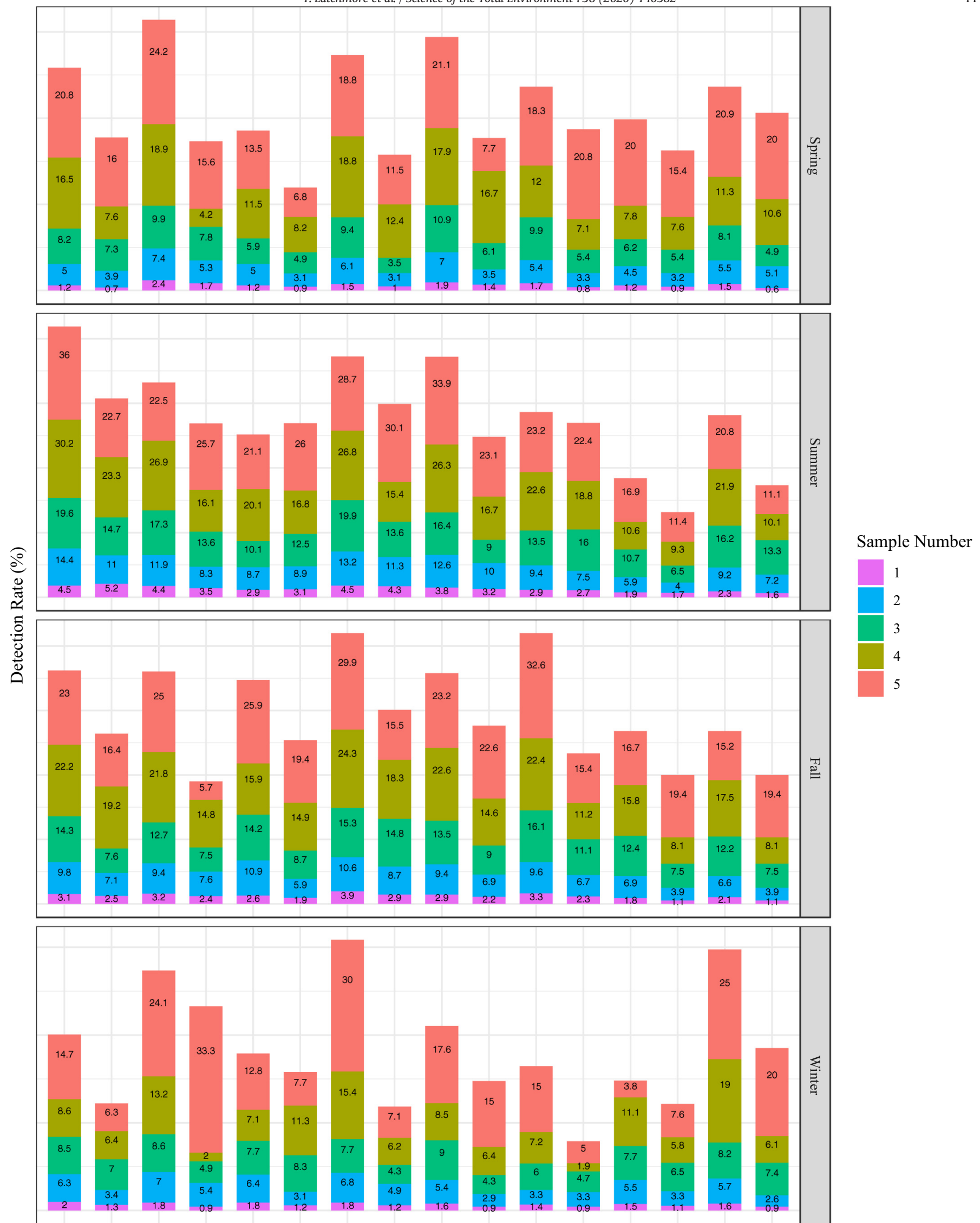

2010C 2010U 2011C 2011U 2012C 2012U 2013C 2013U 2014C 2014U 2015C 2015U 2016C 2016U 2017C 2017U Year $(\mathrm{C}=$ Consolidated Aquifer, $\mathrm{U}=$ Unconsolidated Aquifer $)$

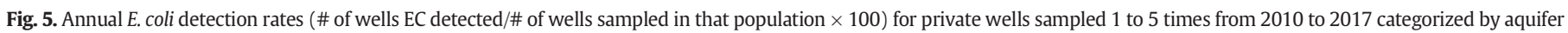
type and season. 


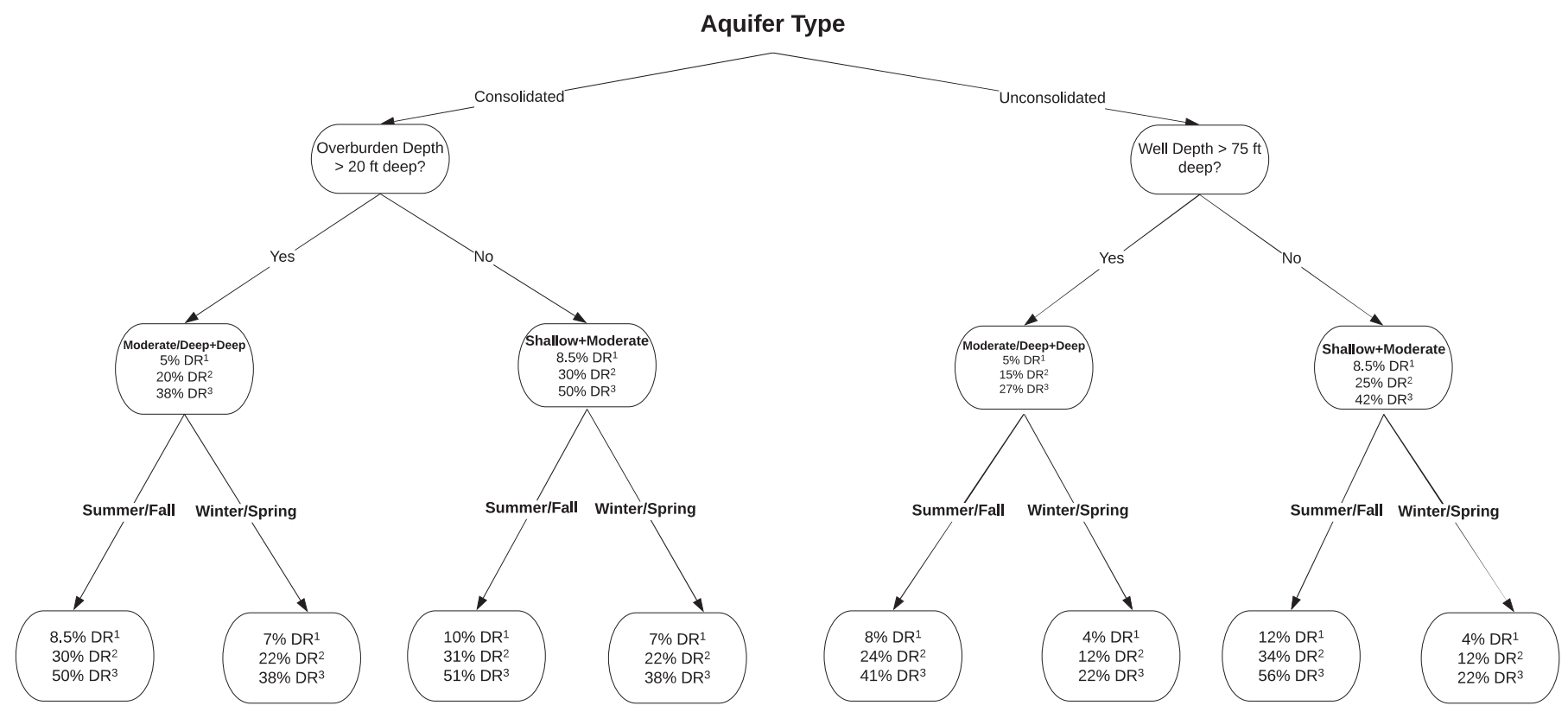

Fig. 6. Detection rate estimates based on the respective delineations in the 2010 to 2017 dataset. $1=3$ times annually, $2=12$ times annually, $3=24$ times annually.
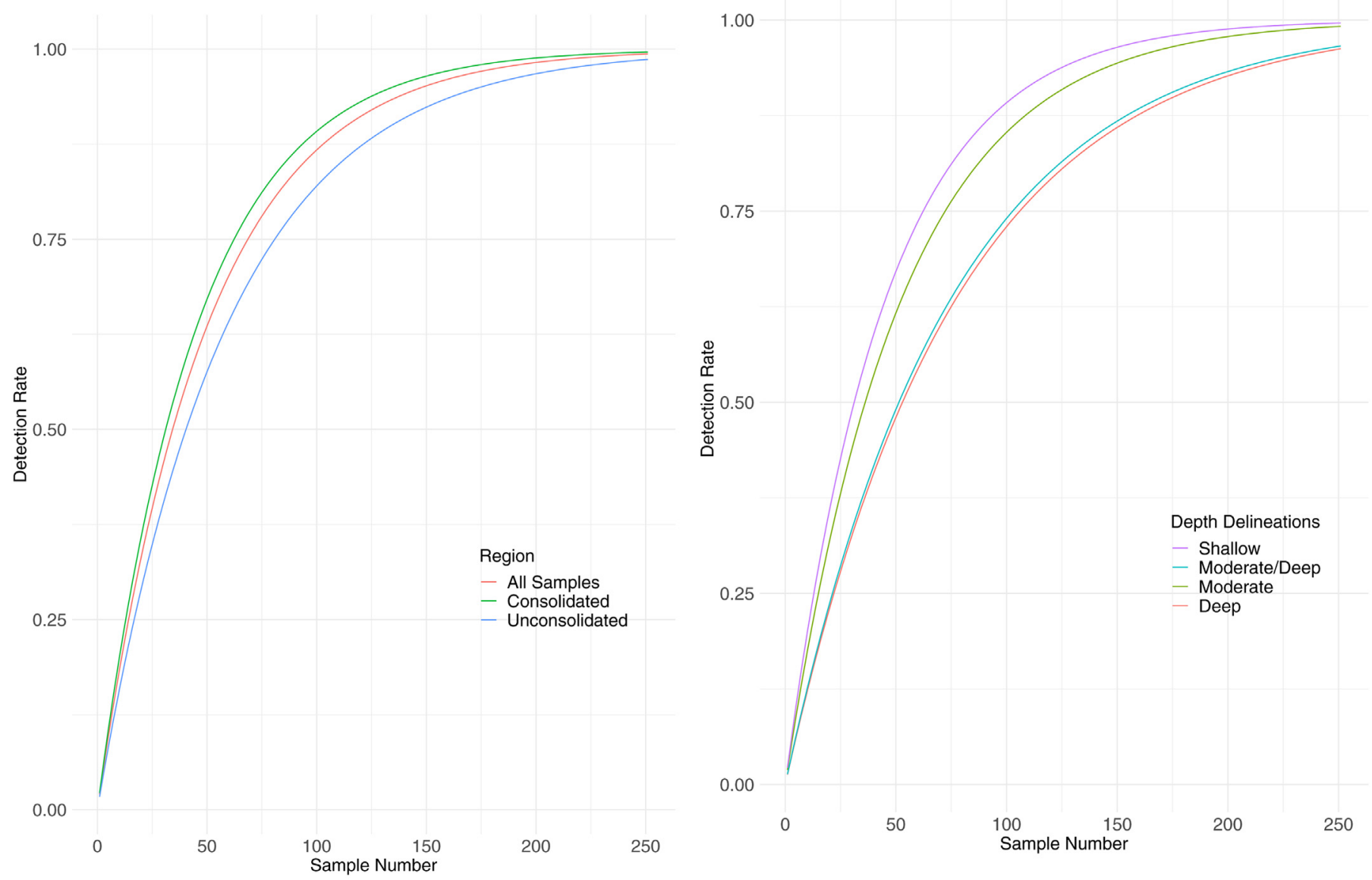

$\mathbf{a}$

b

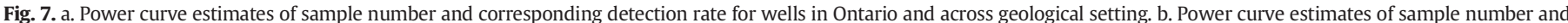

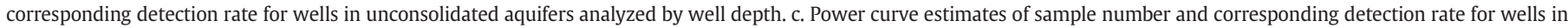

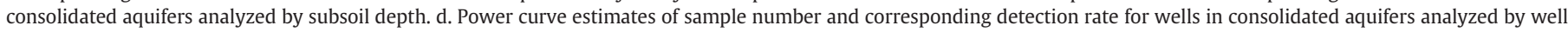
depth. e. Power curve estimates of sample number and corresponding detection rates for wells analyzed by seasons. 


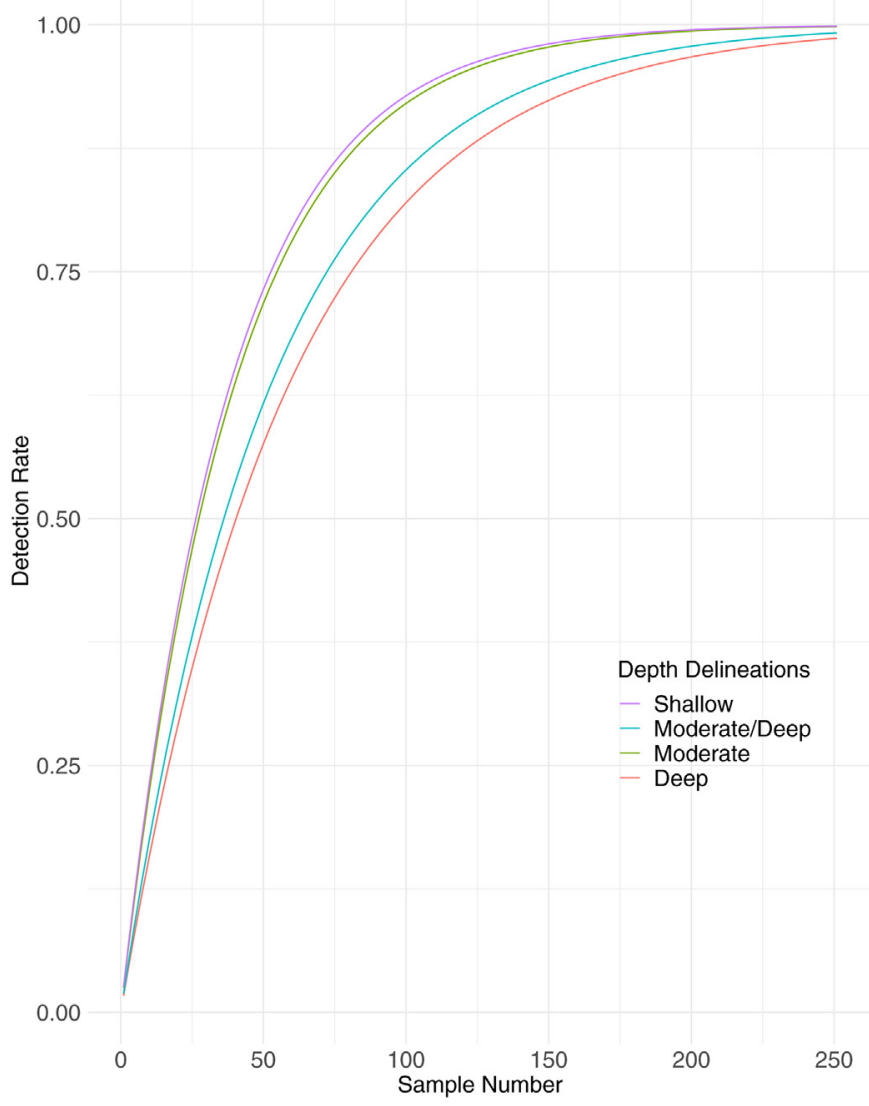

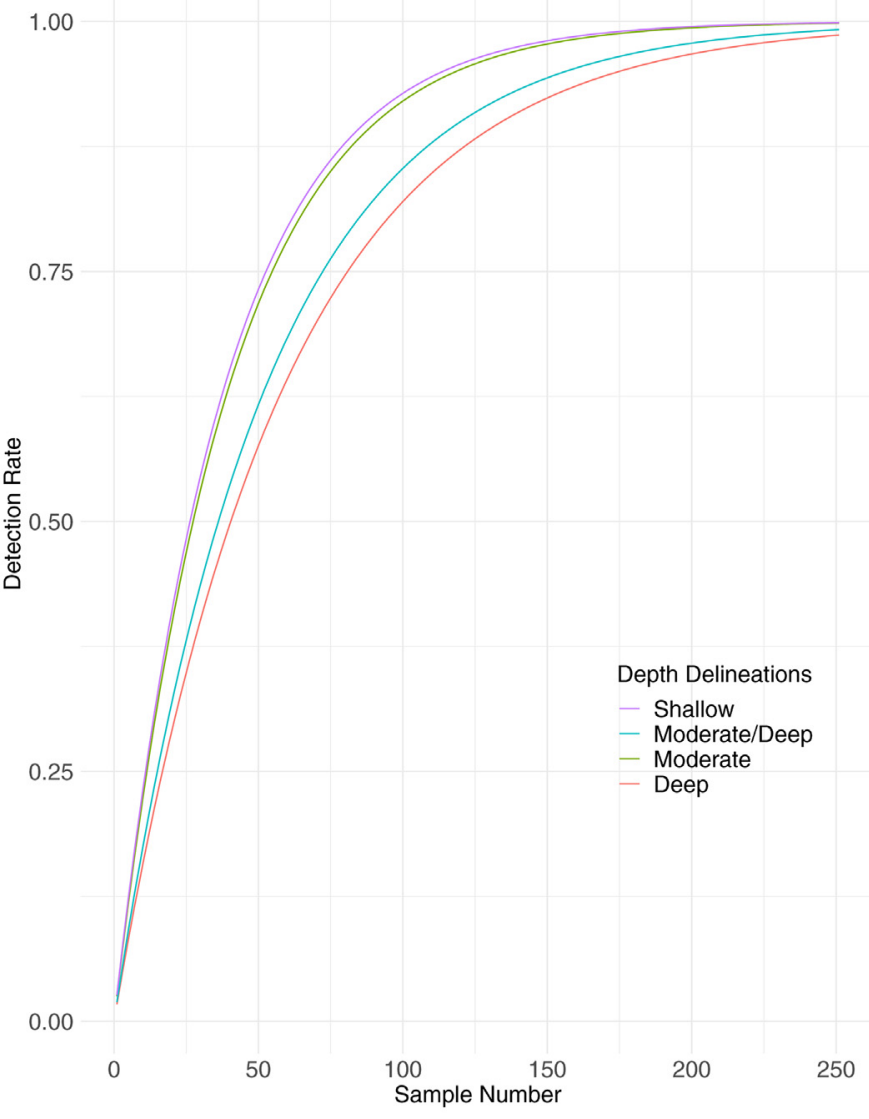

d

Fig. 7 (continued).

limestones and sandstones (Hynds et al., 2012; Atherholt et al., 2013). While underlying limestones and shales were associated with highest detection rates in the current study, sandstone bedrocks were associated with the lowest $E$. coli detection rates. Ontario has many areas with continuous or intermittent layers of shale or "hardpan" in addition to limestone (Conboy and Goss, 2000). For example, limestone bedrocks are typically characterized by relatively high hydraulic conductivity, leading to increased levels of microbial transport and mobility and intermittent limestone layers can contribute to higher contaminant mobility in bedrock that is mostly shale or hardpan (Medici et al., 2019). Thus, associated recharge/infiltration coefficients and velocities may result in maintained pathogen viability and infectivity upon ingress to groundwater sources, in addition to higher pathogen concentrations due to decreased attenuation via filtration, retention and/or microbial predation (Wallender et al., 2014)

Unconsolidated aquifers are typically composed of layers of silts, sands, clays and gravels, with clay and silt layers offering higher rates of attenuation due to their inherently lower permeability and thus reduced transmissivity (Conboy and Goss, 2000). Additionally, silts and clays may influence microbial survival through changes in $\mathrm{pH}$, nutritional status, and increased subsurface retention (i.e. increased time required to reach the aquifer) (Bradford et al., 2015). Higher detection rates encountered among shallow and moderate depth wells in both consolidated and unconsolidated aquifers point to more localized, source-specific contamination mechanisms being associated with private well water as opposed to more generalized aquifer contamination. Localized mechanisms tend to be related to direct bacterial ingress at the wellhead (as a result of poorly constructed or maintained wells) or rapid and/or shallow preferential groundwater pathways (i.e. bypass mechanisms), and thus, higher contaminant concentrations due to increased sensitivity to high-intensity precipitation events and surface runoff (Simpson, 2004; Hynds et al., 2012; Hynds et al., 2014a). The higher detection rates during 2013 (high rainfall intensity year) also support the proposition of localized contamination pathways as shallow wells in particular may experience direct rapid ingress as a result of heavy rainfall, resulting in elevated detection rates. Localized contamination pathways can be mitigated through proper well stewardship behaviours (proper well maintenance and construction) as well as by following the Government of Ontario's directive during well construction which states that a new drilled well should be at least $15 \mathrm{~m}$ (30 $\mathrm{m}$ for dug wells) from sources of contamination (Government of Ontario, 2014).

The spatially-specific findings outlined above leave little doubt as to the influence of hydrogeological setting on E. coli detection rates in private wells in Ontario, and also support the hypothesis that the human health burden associated with these supplies is additionally influenced by location as it relates to hydrogeological setting. However, to date, few if any human health assessments of waterborne infection have accounted for these spatial delineations (Eisenberg et al., 2012; Brouwer et al., 2018). For example, the higher detection rates associated with consolidated aquifers may serve as an evidence-based starting point for future risk assessments of the human health burden associated with private well water, insofar as, human exposures are likely mediated by the aquifer type in which a well is constructed. Accordingly, delineated health risk assessments based on spatial drivers may provide increasing accurate estimation of the human burden given the significant role geology plays in bacterial transport and detection and may also assist in the 


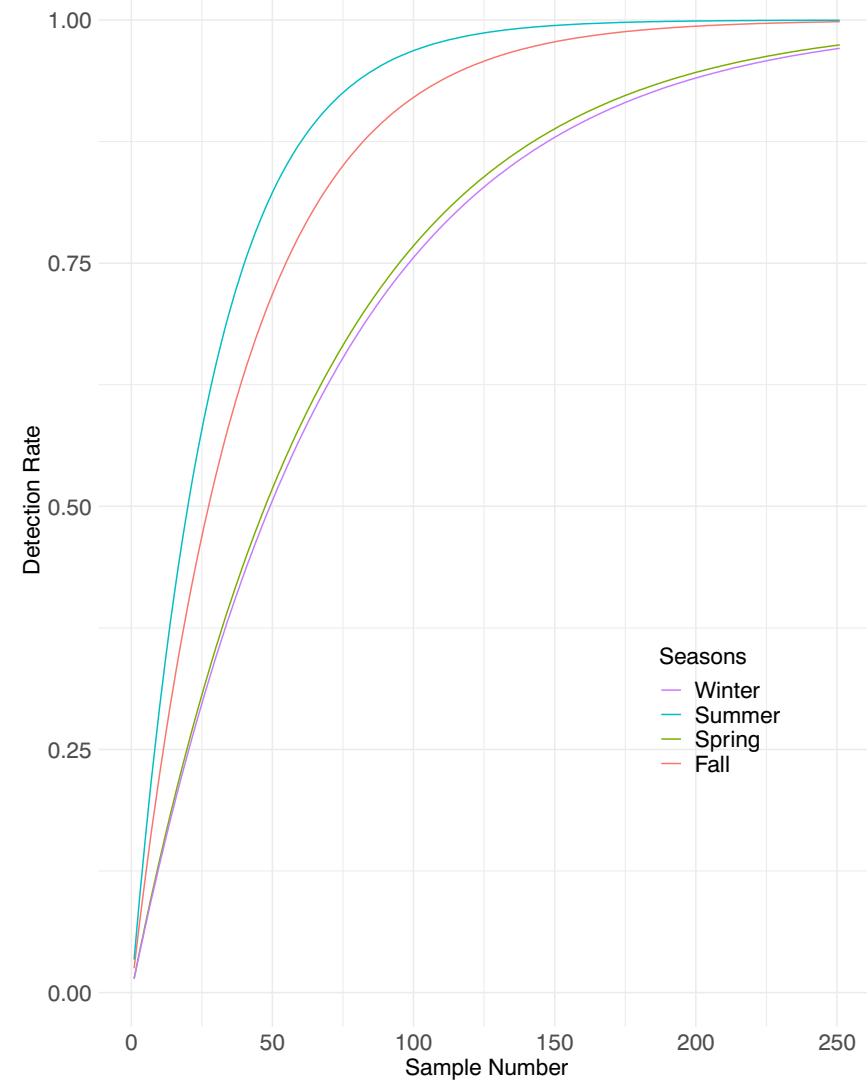

Fig. 7 (continued).

development of evidence-based guidance for well water sampling/ testing.

\subsection{Repeat sampling and E. coli detection}

The variability associated with $E$. coli detection rates was explored by estimating sentinel sampling rates for private wells sampled three times, twelve times and twenty-four times on an annual basis (Fig. 6). Sentinel sampling simulations provide further evidence of the level of variation associated with regionally specific factors (e.g. season, depth, geological formation), as they pertain to E. coli detection. As sample size increases on an annual basis, so too does detection rate, likely moving the well user closer to the "temporal truth" of their personal well water quality. The use of sentinel sampling rates may also be used to inform guidelines for well owners regarding the most appropriate time to test their water supplies. For example, in the case of individuals sampling their well one to three times per year (following guidelines from several Canadian provinces), power curves indicate that sampling during summer months may provide a more realistic picture of overall well water susceptibility. It is important to note that all detection rates presented in the current study are solely based on E. coli as a fecal indicator, and therefore no definitive conclusion about the presence or detection of waterborne pathogens including enteric viruses or protozoa in private well water can be definitively drawn. However, previous studies have presented positive correlations between $E$. coli in private groundwater systems and the presence and concentration of general bacterial pathogens ( $r=0.636, p=0.02$; Hynds et al., 2014a) and Shigella spp. ( $r=0.44, p<0.01$; Ferguson et al., 2012).

Findings from this study echo those reported by Atherholt et al. (2015) who calculated single submission detection rates of $2.1 \%$, $3.3 \%$ and $1.0 \%$ for i) the entire state of New Jersey, ii) the Bedrock (i.e. consolidated) region and iii) Coastal Plain (i.e. unconsolidated) region, respectively. In the current study, single submission detection rates for i) all of Ontario, ii) consolidated aquifers and iii) unconsolidated aquifers were found to be $2.0 \%, 2.2 \%$ and $1.7 \%$, respectively. The current study almost certainly represents the largest of its kind to date, with generated results, conclusions and recommendations based on $>700,000$ submitted samples from almost 240,000 wells over an eight-year period, highlighting the high degree of undertesting in the province. As such, it is evident that one sample is not adequate for an accurate determination of the long-term potability of private groundwater supplies. The degree of potential undertesting of private wells in the province represents a major barrier in understanding the true impact that these systems have on human health. Additionally, submitted samples are often used to create an overall picture of private well water quality and contamination rates, which are frequently presented in published government documents and may misrepresent the status of private well water quality in the province. The sampling bias presented may mask true water quality problems and hinder the potential development of intervention and mitigation strategies for private well owners, as the magnitude of the human health risk associated with these systems remains underestimated (Qayyum et al., 2020).

Results indicate that $E$. coli detection varies considerably depending on season, hydrogeological setting, and well depth. Guidance on testing frequency should account for the aforementioned variables by providing site-specific recommendations for well owners that highlight the dynamic nature of groundwater quality. For example, suggesting an increase in testing frequency during summer months for those located in consolidated aquifers may identify more susceptible wells, and allow for appropriate mitigation strategies to be put in place. Similarly, in the Republic of Ireland and United States, several factors including bedrock type, local subsoil type and depth, climate and septic tank setback distance have been shown to influence the risk of private groundwater contamination (Borchardt et al., 2004; Hynds et al., 2012). Thus, the current study serves as a strong evidence base for the development of regionally- and/or seasonally-specific private well testing frequencies, both in Ontario and further afield, and particularly in regions characterized by a high level of private groundwater reliance or similar contamination risk factors.

\section{Conclusion}

Provincial sampling data from 239,244 wells (702,861 samples) analyzed between 2010 and 2017 was employed to determine E. coli detection rates in private well water in Ontario. Both spatial and temporal factors were found to influence $E$. coli detection rates significantly, highlighting the fluid nature of groundwater quality and the risk of well water contamination in rural and remote areas of the province. In order to gain an accurate representation of private well water contamination, it is recommended that well owners adopt a testing regimen reflective of the well location and groundwater source. However, private drinking water systems are unregulated and therefore the onus is on the well owner to ensure their well is appropriately located, designed, constructed, maintained and that the water is safe to drink. To date, few tools and resources for private well owners have been developed that address the full scope of well water contamination and human illness (Hoffman et al., 2019). A recent review examining effective outreach methods for private well owners concluded that well owners require guidance on how often they should test their water and what they should test for (Morris et al., 2016). Providing generalized recommendations for a province as geographically diverse and spatially extensive as Ontario may unintentionally subject well owners to contaminated groundwater, leading to waterborne illness. An understanding of the factors that contribute to (e.g. hydrogeological setting) and prevent (e.g. well maintenance and testing) contamination events is essential if well owners are to consider test results to inform their 
overall household water safety plans. Future health risk assessments and guidelines for private well water, should consider the impact of spatial and temporal factors on the susceptibility of these supplies, and thus the exposures of users, leading to an increasingly accurate depiction of private well water contamination and the effect on human health.

This work highlights the need for risk assessments of private drinking water systems to be delineated based on the significant drivers of contamination, which, in the context of this study are hydrogeological setting, well depth and season. Future health risk assessments, such as QMRA, and analyses of the impact of private well water on human health should consider i) employing repeat sampling methods over an extended period of time as opposed to one-off sampling in order to gain a more accurate representation of well water contamination (i.e. source susceptibility) and to properly evaluate changes in water quality, and ii) creating multiple risk assessments based on the social and physical factors that influence local private well water contamination. Ultimately, this will facilitate a more comprehensive understanding of the pathways and factors of contamination and minimize potential health burdens attributed to contaminated private drinking water systems.

Supplementary data to this article can be found online at https://doi. org/10.1016/j.scitotenv.2020.140382.

\section{CRediT authorship contribution statement}

Tessa Latchmore: Conceptualization, Data curation, Formal analysis, Investigation, Methodology, Writing - original draft, Writing - review \& editing. Paul Hynds: Conceptualization, Investigation, Methodology, Supervision, Writing - review \& editing. R. Stephen Brown: Conceptualization, Funding acquisition, Supervision, Writing - review \& editing. Corinne Schuster-Wallace: Conceptualization, Writing - review \& editing. Sarah Dickson-Anderson: Conceptualization, Writing - review \& editing. Kevin McDermott: Conceptualization, Data curation, Writing - review \& editing. Anna Majury: Conceptualization, Funding acquisition, Supervision, Writing - review \& editing.

\section{Declaration of competing interest}

The authors declare that they have no known competing financial interests or personal relationships that could have appeared to influence the work reported in this paper.

\section{Acknowledgements}

This research was financially supported by the Canadian Foundation for Infectious Diseases (CFID). The authors would like to thank the Public Health Ontario Environmental Microbiology drinking water testing sites as well as Sandra Edelsward, the Public Health Ontario Drinking Water Coordinator. TL would like to thank The Government of Ontario for an Ontario Graduate Scholarship.

\section{References}

Agresti, A., Tarantola, C., 2018. Simple ways to interpret effects in modeling ordinal categorical data. Statistica Neerlandica https://doi.org/10.1111/stan.12130.

Allevi, R.P., Krometis, L.A.H., Hagedorn, C., Benham, B., Lawrence, A.H., Ling, E.J., Ziegler P.E., 2013. Quantitative analysis of microbial contamination in private drinking water supply systems. J. Water Health https://doi.org/10.2166/wh.2013.152.

Andrade, L., O'Dwyer, J., O'Neill, E., Hynds, P., 2018. Surface water flooding, groundwate contamination, and enteric disease in developed countries: a scoping review of connections and consequences. Environ. Pollut. https://doi.org/10.1016/j. envpol.2018.01.104.

Atherholt, T.B., Bousenberry, R.T., Carter, G.P., Korn, L.R., Louis, J.B., Serfes, M.E., Waller, D.A., 2013. Coliform bacteria in New Jersey domestic wells: influence of geology, laboratory, and method. Groundwater https://doi.org/10.1111/j.1745 6584.2012.00997.x.
Atherholt, T.B., Korn, L.R., Louis, J.B., Procopio, N.A., 2015. Repeat sampling and coliform bacteria detection rates in New Jersey domestic wells. Groundw. Monit. Remediat. https://doi.org/10.1111/gwmr.12094.

Atherholt, T.B., Procopio, N.A., Goodrow, S.M., 2017. Seasonality of coliform bacteria detection rates in New Jersey domestic wells. Groundwater https://doi.org/10.1111/ gwat.12482.

Baldwin, D.J.B., Desloges, J.R., Band, L.E., 2011. Physical Geography of Ontario. Ecol. a Manag. Terr. Landsc. Patterns Process. For. Landscapes Ontario. p. 12.

Bedrock Geology of Ontario [map], 2019. Scale 1:250 000. Data Layers: Bedrock Units; Ministry of Energy, Northern Development and Mines [Computer Files]. Queen's University, Kingston, ON: Generated by Tessa Latchmore, June 24, 2019. Using: ArcGIS for Desktop Advanced [GIS] Version 10.6. Esri, Redlands, CA.

Borchardt, M.A., Haas, N.L., Hunt, R.J., 2004. Vulnerability of drinking-water wells in La Crosse, Wisconsin, to enteric-virus contamination from surface water contributions. Appl. Environ. Microbiol. https://doi.org/10.1128/AEM.70.10.5937-5946.2004.

Bradford, S.A., Schijven, J., Harter, T., 2015. Microbial transport and fate in the subsurface environment: introduction to the special section. J. Environ. Qual. https://doi.org/ 10.2134/jeq2015.07.0375

British Columbia Ministry of Health Services, 2012. Health file \#5b: should I get my well water tested? http://www.healthlinkbc.ca/healthfiles/hfile05b.stm

Brouwer, A.F., Masters, N.B., Eisenberg, J.N.S., 2018. Quantitative microbial risk assessment and infectious disease transmission modeling of waterborne enteric pathogens. Curr. Environ. Heal. reports. https://doi.org/10.1007/s40572-018-0196-X.

Canadian Meteorological and Oceanographic Society, 2018. Top ten weather stories. https://cmos.in1 touch.org/site/top_ten?a=2016.

Card, K.D., Poulsen, K.H., 2013. Geology and mineral deposits of the Superior Province of the Canadian Shield. Geology of the Precambrian Superior and Grenville Provinces and Precambrian Fossils in North America. https://doi.org/10.1130/dnag-gna-c1.13.

Charrois, J.W.A., 2010. Private drinking water supplies: challenges for public health. Can. Med. Assoc. J. 182, 1061-1064. https://doi.org/10.1503/cmaj.090956.

Conboy, M.J., Goss, M.J., 2000. Natural protection of groundwater against bacteria of fecal origin. J. Contam. Hydrol. https://doi.org/10.1016/S0169-7722(99)00100-X.

Conservation Corps Newfoundland and Labrador, 2013. Well aware. Well maintenance: water testing. https://www.mae.gov.nl.ca/waterres/cycle/groundwater/well/toc intro.pdf.

Conway, T., Cohen, P.S., 2015. Commensal and pathogenic Escherichia coli metabolism in the gut. Microbiol Spectr 3. https://doi.org/10.1128/microbiolspec.MBP-0006-2014. Commensal.

Di Pelino, S., Schuster-Wallace, C., Hynds, P.D., Dickson-Anderson, S.E., Majury, A., 2019. A coupled-systems framework for reducing health risks associated with private drinking water wells. Canadian Water Resources Journal/Revue canadienne des ressources hydriques https://doi.org/10.1080/07011784.2019.1581663.

Eisenberg J Trostle, J Sorensen, R., Shield, K, 2012. Towards a systems approach to enteric pathogen transmission: from individual independence to community interdependence. Annu. Rev. Public Health 33, 239-257. https://doi-org.proxy.queensu.ca/ 10.1146/annurev604publhealth-031811-124530

Ferguson, A.S., Layton, A.C., Mailloux, B.J., Culligan, P.J., Williams, D.E., Smartt, A.E., Sayler, G.S., Feighery, J., McKay, L.D., Knappett, P.S.K., Alexandrova, E., Arbit, T., Emch, M., Escamilla, V., Ahmed, K.M., Alam, M.J., Streatfield, P.K., Yunus, M., van Geen, A., 2012. Comparison of fecal indicators with pathogenic bacteria and rotavirus in groundwater. Sci. Total Environ. https://doi.org/10.1016/j.scitotenv.2012.05.060.

Francy, D.S., Helsel, D.R., Nally, R.A., 2000. Occurrence and distribution of microbiological indicators in groundwater and stream. Water Environ. Res. https://doi.org/10.2307/ 25045352.

Galway, L.P., Allen, D.M., Parkes, M.W., Takaro, T.K., 2014. Seasonal variation of acute gastro-intestinal illness by hydroclimatic regime and drinking water source: a retrospective population-based study. J. Water Health https://doi.org/10.2166/ wh.2013.105.

Gao, C., 2011. Buried bedrock valleys and glacial and subglacial meltwater erosion in Southern Ontario, Canada. Can. J. Earth Sci. https://doi.org/10.1139/e10-104.

Gao, C., Shirota, J., Kelly, R.I., Brunton, F.R., Van Haaften, S., 2006. Bedrock topography and overburden thickness mapping, Southern Ontario. Ontario Geol. Surv. 34.

Gonzales, T.R., 2008. The effects that well depth and wellhead protection have on bacterial contamination of private water wells in the Estes Park Valley, Colorado. J. Environ. Health 71, 17-23.

Government of Alberta, 2020. Testing farm drinking water. https://www.alberta.ca/testing-farm-drinking-water.aspx (Accessed April 9, 2020).

Government of Canada, 2019. Historical climate data. https://climate.weather.gc.ca/historical_data/search historic data_e.html (accessed September 21 2020).

Government of Manitoba, 2013. Private wells -bacteriological testing. https://www.gov. mb.ca/waterstewardship/odw/public-info/water-well/index.html.

Government of New Brunswick, 2013. Well water testing. http://www2.gnb.ca/content/ gnb/en/services/services_renderer.3877.html\#serviceFees (Accessed April 9, 2019).

Government of Ontario, 2014. Ontario Water Resources Act R.R.0. 1990, Regulation 903 Wells. https://www.ontario.ca/laws/regulation/900903\#BK1 (Accessed May 20, 2020).

Government of Saskatchewan, 2012. Water testing - common questions. http://www. health.gov.sk.ca/water-testing-common-questions.

Health Canada, 2020. Guidelines for Canadian drinking water quality: guidelines techincal document - Escherichia coli. https://www.canada.ca/en/health-canada/services/publications/healthy-living/guidelines-ca>nadian-drinking-water-quality-guidelinetechincal-document-escherichia-coli.html.

Hoffman, T., Hynds, P., Schuster-Wallace, C., Dickson-Anderson, S., Majury, A., 2019. Harnessing smart technology for private well risk assessment and communication. Water Secur https://doi.org/10.1016/j.wasec.2019.100026. 
Hynds, P.D., Misstear, B.D., Gill, L.W., 2012. Development of a microbial contamination susceptibility model for private domestic groundwater sources. Water Resour. Res. https://doi.org/10.1029/2012WR012492.

Hynds, P.D., Misstear, B.D., Gill, L.W., Murphy, H.M., 2014a. Groundwater source contamination mechanisms: physicochemical profile clustering, risk factor analysis and multivariate modelling. J. Contam. Hydrol. https://doi.org/10.1016/j.jconhyd.2014.02.001.

Hynds, P.D., Gill, L.W., Misstear, B.D., 2014b. A quantitative risk assessment of verotoxigenic E. coli (VTEC) in private groundwater sources in the Republic of Ireland. Hum. Ecol. Risk. Assess. 20, 1446-1468. https://doi.org/10.1080/ 10807039.2013.862065.

Jones, A.Q., Dewey, C.E., Doré, K., Majowicz, S.E., McEwen, S.A., David, W.T., Eric, M., Carr, D.J., Henson, S.J., 2006. Public perceptions of drinking water: a postal survey of residents with private water supplies. BMC Public Health https://doi.org/10.1186/14712458-6-94.

Kettles, I.M., 1992. Glacial Geology and Glacial Sediment Geochemistry in the Clyde ForksWestport Area of Ontario. Geological Survye of Cananda (No.17).

Kreutzwiser, R., de Loë, R.C., Imgrund, K., 2010. Out of Sight, Out of Mind: Private Water Well Stewardship in Ontario. Report on the Findings of the Ontario Household Water Well Owner Survey 2008. Water Policy Gov. Group, Univ. Waterloo, Waterloo, ON.

Levison, J.K., Novakowski, K.S., 2012. Rapid transport from the surface to wells in fractured rock: a unique infiltration tracer experiment. J. Contam. Hydrol. https://doi.org/ 10.1016/j.jconhyd.2012.01.001.

Levy, K., Woster, A.P., Goldstein, R.S., Carlton, E.J., 2016. Untangling the impacts of climate change on waterborne diseases: a systematic review of relationships between diarrheal diseases and temperature, rainfall, flooding, and drought. Environ. Sci. Technol. https://doi.org/10.1021/acs.est.5b06186.

Maier, A., Krolik, J., Randhawa, K., Majury, A., 2014. Bacteriological testing of private well water: a trends and guidelines assessment using five years of submissions data from southeastern Ontario. Can. J. Public Heal., 105 https://doi.org/10.1007/978-3-31939264-6_13.

Medici, G., West, L.J., Banwart, S.A., 2019. Groundwater flow velocities in a fractured carbonate aquifer-type: implications for contaminant transport. J. Contam. Hydrol. https://doi.org/10.1016/j.jconhyd.2019.02.001.

Ministère du Développement durable, de l"Environnement, de la Faune et des Parcs Québec, 2002. The quality of my well water. http://www.mddefp.gouv.qc.ca/eau/potable/depliant/index-en.htm.

Ministry of the Environment, Conservation and Parks, 2014. 2014 annual report of the Office of the Auditor General of Ontario. http://www.auditor.on.ca/en/content/ annualreports/arbyyear/ar2014.html.

Ministry of the Environment, Conservation and Parks, 2019. Weather and meterology. https://www.ec.gc.ca/meteoweather/default.asp?lang $=\mathrm{EN} \& N=6 \mathrm{~A} 4 \mathrm{~A} 3 \mathrm{AC} 5-1$ (accessed April 7 2019).

Morris, L., Wilson, S., Kelly, W., 2016. Methods of conducting effective outreach to private well owners - a literature review and model approach. J. Water Health 14, 167-182. https://doi.org/10.2166/wh.2015.081.

Mosley, L.M., 2015. Drought impacts on the water quality of freshwater systems; review and integration. Earth Sci. Rev. https://doi.org/10.1016/j.earscirev.2014.11.010.

Murphy, H.M., Thomas, M.K., Schimdt, P.J., Medeiros, D.T., McFadyn, S., Pintar, K.D.M., 2016. Estimating the burden of acute gastrointestinal illness due to Giardia, Cryptosporidium, Campylobacter, E. coli 0157 and norovirus associated with private wells and small water systems in Canada. Epidemiol. Infect. 144, 1355-1370. https://doi. org/10.1017/S0950268815002071.

Nova Scotia Environment, 2013. Tips for testing your well water. http://www.gov.ns.ca/ nse/water/welltips.asp.

Ontario Water Resource Act R.S.O, 1990. O.40. https://www.ontario.ca/laws/statute/ 90040 (accessed May 20 2020).

Pons, W., Young, I., Truong, J., Jones-Bitton, A., McEwen, S., Pintar, K., Papadopoulos, A. 2015. A systematic review of waterborne disease outbreaks associated with small non-community drinking water systems in Canada and the United States. PLoS One 10, 1-18. https://doi.org/10.1371/journal.pone.0141646.

Prince Edward Island Department of Environment, Labour and Justice, 2013. Water testing for homeowners. http://www.gov.pe.ca/environment/index.php3?number= 1038048 \&lang $=\mathrm{E}$.

Public Health Ontario, 2018. Bacteriological analysis of drinking water for private citizen requisition form. Public Health Ontariohttps://www.publichealthontario.ca/-/media/ documents/lab/drinking-water-private-citizen.pdf?la=en.

Qayyum, S., Hynds, P., Richardson, H., McDermott, K., Majury, A., 2020. A geostatistical study of socioeconomic status (SES), rurality, seasonality and index test results as drivers of free private groundwater testing in southern Ontario, 2012-2016. Sci. Total Environ. https://doi.org/10.1016/j.scitotenv.2020.137188.

Richardson, H.Y., Nichols, G., Lane, C., Lake, I.R., Hunter, P.R., 2009. Microbiological surveillance of private water supplies in England - the impact of environmental and climate factors on water quality. Water Res. https://doi.org/10.1016/j.watres.2009.02.035.

Roche, S.M., Jones-Bitton, A., Majowicz, S.E., Pintar, K.D.M., Allison, D., 2013. Investigating public perceptions and knowledge translation priorities to improve water safety for residents with private water supplies: a cross-sectional study in Newfoundland and Labrador. BMC Public Health 13. https://doi.org/10.1186/1471-2458-13-1225.

Rural Ontario Institute, 2017. Focus on rural Ontario fact sheet series - 2016 edition. https://www.ruralontarioinstitute.ca/uploads/userfiles/files/2016\%20FOCUS\%200N\% 20RURAL\%200NTARIO\%20BOOK\%20-\%20FINAL.pdf.

Schuster, C., Ellis, A., Robertson, W., Charron, D., Aramini, J., Marshall, B., Medeiros, D., 2005. Infectious disease outbreaks related to drinking water in Canada, 1974-2001. Can. J. Public Heal. 96, 254-258.

Simpson, H., 2004. Promoting the management and protection of private water wells. Journal of Toxicology and Environmental Health - Part A https://doi.org/10.1080/ 15287390490492296.

Smith, A., Reacher, M., Smerdon, W., Adak, G.K., Nichols, G., Chalmers, R.M., 2006. Outbreaks of waterborne infectious intestinal disease in England and Wales, 1992-2003. Epidemiol. Infect. https://doi.org/10.1017/S0950268806006406.

Statistics Canada, 2016. Households and the Environment Survey, 2015. Stat. Canada.

Ugas, M., Pearl, D.L., Zentner, S., Tschritter, D., Briggs, W., Manser, D., Trotz-Williams, L.A., 2019. Examining the factors related to bacteriological testing of private wells in southern Ontario. J. Water Health https://doi.org/10.2166/wh.2019.164.

Wallender, E.K., Ailes, E.C., Yoder, J.S., Roberts, V.A., Brunkard, J.M., 2014. Contributing factors to disease outbreaks associated with untreated groundwater. Groundwater https://doi.org/10.1111/gwat.12121.

WHO, 2017. Guidelines for Drinking-water Quality: Fourth Edition Incorporating the First Addendum. WHO https://doi.org/10.2105/AJPH.17.2.162-b. 